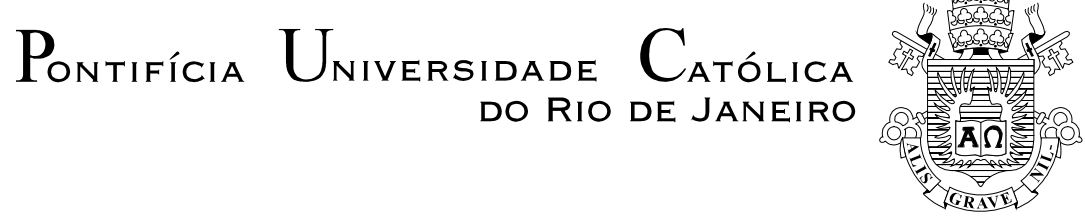

Carlos Gustavo Camillo Pereira

\title{
Polissemia do prefixo "des-" em substantivos de ação no Português Brasileiro: uma análise da língua em uso
}

Dissertação de Mestrado

Dissertação apresentada como requisito parcial para obtenção do grau de Mestre pelo Programa de Pós-graduação em Estudos da Linguagem do Departamento de Letras da PUC-Rio

Orientadora: Profa. Margarida Maria de Paula Basilio 


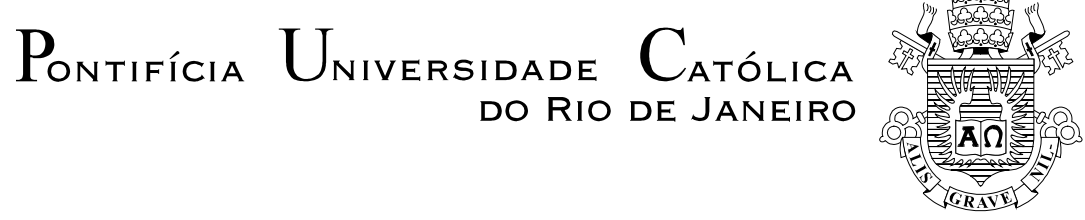

Carlos Gustavo Camillo Pereira

\begin{abstract}
Polissemia do prefixo "des-" em substantivos de ação no Português Brasileiro:

uma análise da língua em uso
\end{abstract}

Dissertação apresentada como requisito parcial para obtenção do grau de Mestre pelo Programa de Pós-graduação em Estudos da Linguagem da PUC-Rio. Aprovada pela Comissão Examinadora abaixo.

Profa. Margarida Maria de Paula Basílio

Orientadora

Departamento de Letras - PUC-Rio

Profa. Rosa Marina de Brito Meyer

Departamento de Letras - PUC-Rio

Prof. Carlos Alexandre Victorio Gonçalves

UFRJ

Prof. José Carlos Santos de Azeredo

UERJ

Rio de Janeiro, 20 de fevereiro de 2020. 
Todos os direitos reservados. É proibida a reprodução total ou parcial deste trabalho sem a autorização da universidade, do autor e da orientadora.

\section{Carlos Gustavo Camillo Pereira}

Graduou-se em Letras Português e Inglês pela Universidade Veiga de Almeida (UVA/RJ) em 2017. Tornou-se especialista em Língua Portuguesa pelo Liceu Literário Português em 2020, mesmo ano em que concluiu o mestrado em Estudos da Linguagem pela Pontifícia Universidade Católica do Rio de Janeiro (PUC-Rio), onde foi bolsista do Conselho Nacional de Desenvolvimento Científico e Tecnologia (CNPq)

Ficha Catalográfica

Pereira, Carlos Gustavo Camillo

Polissemia do prefixo "des-" em substantivos de ação no português brasileiro : uma análise da língua em uso / Carlos Gustavo Camillo Pereira ; orientadora: Margarida Maria de Paula Basilio. 2020.

91 f. ; $30 \mathrm{~cm}$

Dissertação (mestrado)-Pontifícia Universidade Católica do Rio de Janeiro, Departamento de Letras, 2020.

Inclui bibliografia

1. Letras - Teses. 2. Prefixo des-. 3. Formação de palavras. 4. Morfologia. 5. Polissemia. 6. Língua em uso. I. Basilio, Margarida Maria de Paula. II. Pontifícia Universidade Católica do Rio de Janeiro. Departamento de Letras. III. Título. 
Dedicado a minha esposa, a meus pais e a todos os pesquisadores dos estudos lexicais. 


\section{Agradecimentos}

A Deus, meu Senhor, meu Mestre, Meu guia que me concedeu o privilégio, a sabedoria e o conhecimento necessários para iniciar e concluir este curso de mestrado. Sua grandiosa bondade e misericórdia têm me sustentado desde o primeiro suspiro da minha existência. Uma vida inteira de gratidão ainda é infinitamente pouco diante de tamanha benignidade para comigo.

À minha estimada orientadora Margarida Basílio, profissional inigualável e de vasta experiência e importância na área dos estudos lexicais. Sua orientação é sempre firme, presente e desafiadora. Suas contribuições fizeram com que eu refletisse a todo momento da realização deste trabalho.

À Pontifícia Universidade Católica do Rio de Janeiro (PUC-Rio) e ao Conselho Nacional de Desenvolvimento Científico e Tecnológico (CNPq) que me concederam recursos indispensáveis para a realização deste trabalho (e deste sonho).

À minha amada esposa Larissa Carmen Domingues de Freitas por ter se mantido tão forte ao meu lado nos momentos em que mais precisei, por ter permitido que eu dividisse minhas angústias e meus fardos durante este trabalhoso caminho. Seu apoio é fundamental. Sem você, certamente minha caminhada não seria tão prazerosa e cheia de alegria como é.

Ao meu determinado pai Carlos Alberto Faria Pereira por ser meu exemplo de caráter, justiça e responsabilidade, que contribuiu para a formação do meu caráter como homem, cidadão, profissional e pesquisador; à minha carinhosa mãe Nilsa Camillo Pereira cujo amor, carinho, delicadeza e sábios conselhos sempre me ajudaram a superar as dificuldades e ter esperança em um futuro melhor.

Ao meu querido irmão Leonardo Camillo Pereira pelo carinho, pelo apoio, por sempre estar ao meu lado e ser meu primeiro amigo verdadeiro.

Aos professores do Programa de Pós-Graduação em Estudos da Linguagem da PUC-Rio (PPGEL) que atuaram como importantes agentes para a construção de meu conhecimento, dos quais destaco Maria das Graças Dias Pereira, Érica dos Santos Rodrigues, Liana de Andrade Biar, Claudia Freitas e Letícia Maria Sicuro Correa.

Aos professores José Carlos Santos de Azeredo, Carlos Alexandre Victório Gonçalves e Rosa Marina de Brito Meyer por terem gentilmente aceitado compor a banca de avaliação deste trabalho e por suas preciosas contribuições para o aprimoramento desta pesquisa.

Aos funcionários do Departamento de Letras da PUC-Rio e, em especial, Francisca Ferreira de Oliveira, nossa querida e insubstituível Chiquinha, pelo carinho, gentileza, solicitude, respeito e palavras de conforto e sabedoria. 


\section{Resumo}

Pereira, Carlos Gustavo Camillo; Basílio, Margarida Maria de Paula. Polissemia do prefixo "des-" em substantivos de ação no Português Brasileiro: uma análise da língua em uso. Rio de Janeiro, 2020, 91p. Dissertação de Mestrado - Departamento de Letras, Pontifícia Universidade Católica do Rio de Janeiro.

Este trabalho investiga as acepções do prefixo "des" em substantivos de ação no Português Brasileiro por meio de uma abordagem da língua em uso e focaliza a importância do contexto para o reconhecimento do sentido que está sendo ativado pelo afixo. Inicialmente, são apresentadas as principais contribuições da Tradição Gramatical Normativa e da Teoria da Linguística Gerativa para a análise do referido prefixo. Posteriormente, são detalhadas as bases teóricas que compõem este trabalho, que se fundamentam nos pressupostos da Linguística Cognitiva, paradigma de investigação dos estudos da linguagem que enfatiza a importância do sentido em uma perspectiva não-objetivista e da investigação da língua em uso. O corpus utilizado nesta pesquisa foi constituído a partir do mega-corpus eletrônico NILC da Universidade de São Paulo do campus de São Carlos. Os resultados da análise de dados revelam que a acepção do afixo "des-" na língua em uso é altamente influenciada pelo contexto, de maneira que é possível uma mesma palavra possuir sentidos diferentes, conforme esteja em diferentes situações de uso.

\section{Palavras-chave}

Prefixo des-; Formação de palavras; Morfologia; Léxico; Língua em uso; Nominalização; Semântica; Polissemia. 


\section{Abstract}

Pereira, Carlos Gustavo Camillo; Basílio, Margarida Maria de Paula (Advisor). Polysemy of the prefix "des-" in action nouns in Brazilian Portuguese: an analysis of the language in use. Rio de Janeiro, 2020, 91p. Dissertação de Mestrado - Departamento de Letras, Pontifícia Universidade Católica do Rio de Janeiro.

This dissertation investigates the meanings of the prefix "des" in action nouns in Brazilian Portuguese through an approach to the language in use and focuses on the importance of context for the recognition of the meaning being activated by the affix. Initially, the main contributions of the Normative Grammatical Tradition and the Theory of Generative Linguistics to the analysis of the referred prefix are presented. Subsequently, the theoretical bases that make up this work are detailed, which are based on the assumptions of Cognitive Linguistics, a research paradigm of language studies that emphasizes the importance of meaning in a non-objectivist perspective and the investigation of the language in use. The corpus used in this research was constituted from the electronic mega-corpus NILC of the University of São Paulo developed on the São Carlos campus. The results of the data analysis reveal that the meaning of the affix "des-" in the language in use is highly influenced by the context, therefore it is possible for the same word to have different meanings, depending on whether it is in different situations of use.

\section{Keywords}

Prefix “des-"; Word formation; Morphology; Lexicon; Language in use; Nominalization; Semantics; Polysemy. 


\section{Sumário}

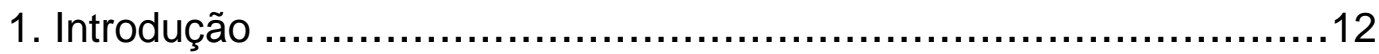

1.1. Considerações preliminares................................................. 12

1.2. Hipóteses de trabalho .........................................................

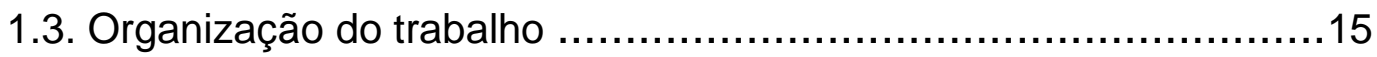

2. O prefixo "des-" e suas abordagens ….....................................16

2.1. As gramáticas tradicionais e suas contribuições para a descrição do prefixo "des-" .................................................................... 16

2.2. Abordagem gerativa: o prefixo como seleção categorial e semântica

2.3. Além das categorias e subcategorias: o argumento interno do verbo e os traços semânticos de lieber .....................................................

2.4. Primeiros olhares para o prefixo em seu contexto de uso ..............27

3. Pressupostos teóricos e metodologia ........................................32

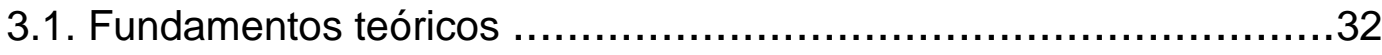

3.1.1. Princípios fundamentais da linguística cognitiva ......................33

3.1.2. Regras analógicas: a possibilidade de análise de casos de baixa

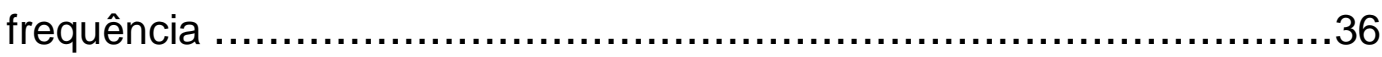

3.1.3. O viés teórico da nominalização: concepção e interpretações .....40

3.1.3.1. Nominalização em uma perspectiva cognitiva .......................42

3.2. Fundamentos metodológicos .............................................43

3.2.1. A construção do corpus e processo de extração de dados .........44

3.2.2. O desenvolvimento das acepções .....................................45

3.2.3. Procedimentos de análise .............................................. 47

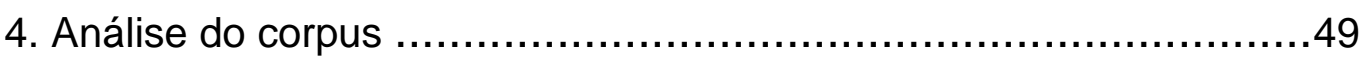

4.1. Nominalização com formação em sufixo (-ção) ........................ 49

4.2. Nominalização com formação em sufixo (-mento) ..................... 55

4.3. Nominalização com sufixos minoritários (-agem, -ança e ência) ...60 
4.4. Substantivos deverbais........................................65

4.5. Resultados das análises ..........................................69

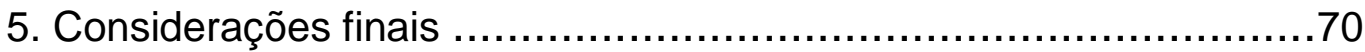

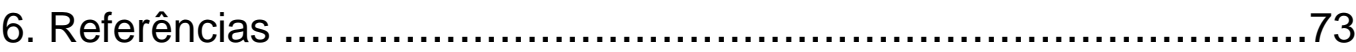

7. Apêndice ........................................................ 77

7.1. Vocábulos formados a partir do sufixo "-ção" ....................... 77

7.2. Vocábulos formados a partir do sufixo "-mento" ......................88

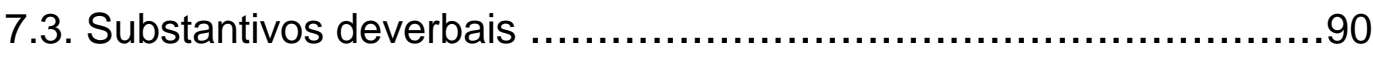




\section{Lista de quadro}

Quadro 1 - Frequência das acepções do prefixo "des-"......................69 
Without links, we could neither be nor be human. We come into existence tethered to our biological mothers by umbilical cords that nourish and sustain us. But this merely physical linking is never the full story of our humanity, which requires a certain nonphysical linking to our parents, our siblings, and our society as a whole. The severing of the umbilical cord launches us into an ongoing process of linking, bonding, and connecting that gives us our identity. 
1.

\section{Introdução}

\section{1.}

\section{Considerações preliminares}

O prefixo des- é amplamente abordado em muitas pesquisas por diversos pesquisadores da Língua Portuguesa, os quais vão desde gramáticos tradicionais até linguistas de diferentes perspectivas teóricas. Adicionalmente, na maioria desses estudos, há um frequente privilégio para a análise das construções do prefixo com bases verbais e, em um segundo plano, com adjetivos. Em relação ao sentido do prefixo, esses trabalhos pressupõem a existência de diferentes tipos de negações, tal como a privação, a contradição, a separação e a falta, sem apresentar, de maneira clara, uma justificativa para a depreensão da negação em diferentes sentidos. Além disso, a reversão também é elencada como uma das possibilidades significativas do afixo e é atribuída regularmente aos verbos.

É importante destacar que as combinações do prefixo com substantivos são pouco estudadas, sendo, às vezes, ignoradas ou consideradas irrelevantes devido ao fato de serem supostamente improdutivas na Língua Portuguesa contemporânea, o que resulta na massiva discrepância, em termos quantitativos, de trabalhos que se propõem analisar as construções "des- + verbo e/ou adjetivo" e "des- + substantivos".

A fim de auxiliar no desenvolvimento de maior reflexão quanto ao sentido do prefixo des- em bases substantivas, este trabalho tem, por objetivo geral, estabelecer uma investigação das acepções do prefixo em substantivos de ação. Em adição, o presente trabalho se fundamenta em uma abordagem teórica diferenciada, baseada na análise da língua em uso, em contraste aos estudos de ordem normativa uma vez que se utilizam de um corpus formado por palavras não transparentes para o falante atual do Português Brasileiro (doravante PB) e das abordagens de cunho gerativista visto que se concentram mais na prescrição ou previsão de impossibilidade, além de, normalmente, não considerarem que o 
contexto em que a palavra está inserida seja relevante para a compreensão da acepção que o prefixo está desempenhando.

Em se tratando da estrutura deste trabalho, sua divisão se dá em cinco principais seções. A primeira trata da revisão de literatura sobre o prefixo "des-". Assim, descrevemos as principais contribuições de pesquisas sobre como este afixo e seus sentidos são concebidos e analisados em perspectivas da Teoria Gramatical Tradicional, do Gerativismo e das primeiras noções do uso do contexto para a compreensão do sentido.

$\mathrm{Na}$ seção posterior, apresentamos as bases teóricas que orientam este trabalho, as quais se sustentam nos princípios da Linguística Cognitiva, mais especificamente, nas perspectivas da Gramática Cognitiva desenvolvida por Langacker (1987, 2008, 2009).

Dessa forma, realçamos a importância de análises que privilegiem a língua em uso e que concebam o sentido em uma perspectiva não-objetivista. Em adição, explicamos a importância da analogia proporcional (Saussure, 1916) para o entendimento do fenômeno da criação de novos vocábulos em detrimento da aderência da noção de formação de palavras (Basilio, 1997). Além disso, também esclarecemos as noções de nominalização que utilizamos neste trabalho uma vez que esta concepção é importante para a compreensão de como se dá a formação do item lexical analisado e de que maneira a polissemia pode ser reconhecida em algumas destas construções.

Adiante, tratamos da metodologia adotada para o empreendimento das análises das palavras prefixadas, as quais devem ser transparentes para o falante contemporâneo do PB. Além disso, os vocábulos que compõem nosso corpus foram extraídos do grande corpus eletrônico do NILC da Universidade de São Paulo em São Carlos, que conta com mais de 32 milhões de palavras anotadas gramaticalmente.

Em se tratando da análise dos vocábulos que constituem nossos dados, eles são analisados considerando seu contexto de utilização. Dessa forma, investigamos a acepção do prefixo "des-" de cada vocábulo considerando os elementos (con)textuais para determinar que sentido está sendo evocado na palavra em questão. 
Devido à possibilidade de coletar um grande número de substantivos transparentes prefixados em "des-", reservamos uma seção, ao final desta dissertação, a fim de observar as acepções do prefixo de todos os outros itens lexicais que não foram contemplados no capítulo de análise de dados.

Por fim, acreditamos que este trabalho, por se basear em uma abordagem de língua que privilegie o uso, possua o potencial de proporcionar uma alternativa diferente no que diz respeito à investigação dos itens lexicais.

\section{2.}

\section{Hipóteses de trabalho}

Este trabalho se desenvolve a partir de quatro hipóteses principais. A primeira é a de que o prefixo des- é polissêmico. Assim, compreendemos que o sentido varia com base no uso e não a partir da existência de dois ou mais prefixos homônimos. Nossa segunda hipótese se baseia no entendimento de que o sentido do prefixo não é acessado de maneira objetiva. Em outras palavras, apenas por meio da consideração do contexto é que, de fato, pode-se compreender o sentido que o prefixo está desempenhando naquele determinado enunciado.

Como consequência dos pressupostos anteriores, nossa terceira hipótese é a de que uma determinada palavra prefixada não possuirá sempre o mesmo sentido uma vez que este é influenciado pelo contexto de uso. Nessa perspectiva, “desvalorização", por exemplo, não será sempre uma "não valorização", mas poderá ser também uma "reversão do estado ou do ato de valorizar" ou, ainda, uma "antivalorização". O que irá determinar uma ou mais dessas possibilidades é o contexto.

Finalmente, compreendemos que a interpretação da nominalização é que determinará a configuração do item lexical. Dessa maneira, se uma determinada nominalização possuir sentido verbal, entendemos que, primeiro, o prefixo se adjungiu ao verbo e, depois, ocorreu a entrada do sufixo nominalizado. Contudo, se a nominalização não apresentar a contraparte do sentido verbal, mas apenas nominal, a construção da palavra se dá pela adição do prefixo diretamente ao 
substantivo. Além disso, é válido destacar que existe a possibilidade de haver as duas interpretações de uma mesma palavra, de forma que o item lexical possuirá duas configurações diferentes a depender da leitura do falante.

\section{3.}

\section{Organização do trabalho}

O desenvolvimento deste trabalho é segmentado da seguinte maneira: inicialmente, tem-se o capítulo de introdução, em que estabelecemos considerações iniciais quanto aos nossos objetivos, bem como a escolha pelo tema e a explicação de nossas hipóteses de trabalho. Posteriormente, no capítulo 2, realizamos a apresentação de diferentes paradigmas referentes aos estudos do prefixo "des". Mais especificamente, abordamos a perspectiva da gramática tradicional e da Linguística Gerativa.

O terceiro capítulo é dividido em duas partes principais. Na primeira, apresentamos a perspectiva teórica da Linguística Cognitiva para a análise da língua. Em adição, também determinamos o conceito de nominalização com que estamos trabalhando e justificamos a adoção do Princípio da Analogia para o tratamento do léxico em detrimento do já tradicional conceito de Regras de Formação de Palavras. Em relação à segunda parte deste capítulo, tratamos dos princípios de extração de palavras do corpus eletrônico NILC a fim de constituir nosso próprio corpus de pesquisa e explicamos como se daria o procedimento de análise das palavras prefixadas.

No quarto capítulo, disponibilizamos uma proposta de análise das acepções do prefixo "des". Adicionalmente, realizamos as análises das palavras dentro de seus contextos de utilização uma vez que nosso objetivo é investigar como os elementos (con)textuais influenciam no sentido que é desempenhado pelo prefixo.

Nas considerações finais, objetivamos responder aos questionamentos fomentados por esta pesquisa, além de proporcionarmos, no apêndice, o sentido do prefixo "des" em todas as outras palavras que não puderam ser contempladas no capítulo de análise de dados. 
2.

\section{O prefixo "des-" e suas abordagens}

Neste capítulo, temos por objetivo analisar pesquisas e trabalhos acadêmicos referentes ao prefixo "des-" a fim de que se torne mais clara a contribuição que este trabalho visa propor para a compreensão dos sentidos do referido afixo em frente à multiplicidade de pesquisas relevantes já produzidas. Inicialmente, analisamos o tratamento viabilizado ao prefixo "des-" em gramáticas normativas do Português de grande difusão no Brasil, sendo estas: Bechara (2009); Cunha \& Cintra (2013) e Rocha Lima (2008). Subsequentemente, apresentamos as propostas dos trabalhos de Silva e Mioto (2009), Oliveira (2004 e 2009) os quais se identificam com a abordagem gerativa. Adiante, citamos as contribuições de Medeiros (2010), de Bona \& Ribeiro (2018) e terminamos o capítulo com a apresentação das pesquisas de Dolinski (1993) e Schneider \& Bidarra (2009) que começam a olhar para a importância do contexto de uso para a análise do sentido que o prefixo está desempenhando.

\section{1.}

\section{As gramáticas tradicionais e suas contribuições para a descrição do prefixo "des-"}

Em se tratando da formação de palavras por meio de prefixos, de acordo com Bechara (2009); Cunha \& Cintra (2013) e Rocha Lima (2008) há uma grande controvérsia se o adequado seria considerar este processo de estruturação como uma composição ou, na verdade, como uma derivação. Todavia, todos concebem esse processo de formação de palavras como sendo uma derivação. Assim, Cunha \& Cintra (2013, p. 98-99) estabelece que, diferentemente dos sufixos, os prefixos são mais independentes que os sufixos uma vez que sua origem geralmente advém de advérbios ou de preposições que têm ou tiveram uso autônomo.

Adicionalmente, os gramáticos também explicam que seria possível, até mesmo, determinar duas classes de prefixos. A primeira seriam os prefixos que 
não possuem existência própria sem que esteja acoplada a uma outra palavra, que seria o caso dos afixos "des-" ou "re-", como em "desfazer" ou "repor", respectivamente. Quando a palavra é formada por este tipo de prefixo, seria o caso de prefixação. No entanto, há prefixos que podem funcionar também como palavras independentes como os prefixos "contra" e "entre", como em "contradizer" e "entreabrir". Uma vez que esse segundo tipo de prefixo é mais autônomo que o primeiro, os gramáticos entendem que, neste caso, que é possível estamos diante de uma composição.

Cunha \& Cintra entendem que não há facilidade para estabelecer tal diferença em todos os casos presentes na língua. Por este motivo, os referidos gramáticos acreditam ser mais adequado considerar que toda formação de palavras a partir da adjunção de um prefixo seja entendido como um caso de prefixação.

No entanto, em se tratando de formação de palavras, as gramáticas normativas limitam-se apenas à criação de uma lista de prefixos mais frequentes de origem grega e latina na Língua Portuguesa e distribuem seus significados básicos ao lado. Além disso, em relação ao prefixo des-, há discordância entre os autores em considerá-lo como variante do prefixo dis- ou se, ao contrário, trata-se de prefixos diferentes.

Bechara (2009, p. 366) estabelece o prefixo des- como sendo uma mera variante do prefixo dis- e, quanto ao seu sentido, determina que ele detém 5 acepções (negação, ação contrária, cessão de um ato ou estado, ablação e intensidade). Contudo, sua categorização é problemática uma vez que não possui o interesse de determinar quais das variantes possui o referido sentido ou se as acepções são as mesmas para cada forma. Essa última proposta não parece ser o caso visto que o gramático não disponibiliza exemplificações de cada acepção para as duas variantes. Seria, então, neste caso, o traço semântico de "negação" próprio à variante des- ou dis-? Tal opacidade nas proposições dificulta a compreensão da descrição do fenômeno linguístico. "De(s), di(s) [...]: desventura, discordância, difícil (dis + fácil), desinfeliz, desfrear (=fazer muito feio), desmudar (=mudar muito).” (op. Cit, p. 367)

Os exemplos disponibilizados em suas proposições não são todas formações transparentes visto que o vocábulo "difícil” pouco provavelmente seria 
reconhecido, por um falante do Português Brasileiro contemporâneo, como caso de palavra derivada. Em adição, Bechara propõe ainda outro prefixo depossuindo outras 4 acepções (movimento para baixo, separação, intensidade, negação), com os seguintes exemplos: "depenar", “decompor", “decair". Entretanto, essas acepções são problemáticas uma vez que o prefixo des- também possui caráter de intensidade e, até mesmo, expressivo.

Por fim, suas proposições de manter os prefixos des- e dis- como sendo os mesmos fomentam mais debates sobre suas emancipações. Além disso, a própria separação entre o prefixo des- e de-, proposta pelo gramático, com base em suas propriedades significativas, é difícil de ser aplicada visto que ambos os prefixos compartilham muitos dos mesmos traços semânticos.

Diferentemente de Bechara, Cunha \& Cintra (2013, p. 99) consideram que os prefixos des- e dis- são afixos diferentes e não devem, portanto, serem analisados como o caso de variação. Em relação aos traços semânticos carregados pelos prefixos, os linguistas determinam que o prefixo des- possui duas acepções (separação e ação contrária) ao passo que o prefixo dis e suas variações di- (dir-) obtém três acepções (separação, movimento para os lados e negação).

Para exemplificar os traços semânticos dos prefixos, os autores estabelecem os vocábulos (desviar e desfazer) para o primeiro e (dissidente, distender, dilacerar e dirimir) para o segundo. No entanto, assim como em Bechara (2009), os linguistas também adotam a postura de se utilizarem de palavras não transparentes para falantes contemporâneos do Português Brasileiro para sustentarem suas proposições. Além disso, o prefixo des- claramente possui, diferentemente do que estabelece a descrição proposta por Cunha \& Cintra, a noção de negação, o que pode ser confirmado por palavras tais como: "desleal", descompromissado", "desafinado" etc.

Finalmente, mais uma vez como em Bechara, Cunha \& Cintra também corroboram com a existência do prefixo "de". o qual afirmam possuir a acepção única de (movimento de cima para baixo), como nos vernáculos “decair" e “decrescer". Assim, as noções de negação e intensidade, por exemplo, não são atribuídas a esse prefixo.

Rocha Lima (2008, p. 203), assim como os linguistas Cunha \& Cintra, afirma que os prefixos des- e dis- não são formas variantes, antes se tratam de 
prefixos diferentes. O gramático elenca quatro sentidos para o prefixo des(separação, privação, ação contrária e negação) e propõe as palavras "desfazer", "desfolhar", “desmascarar", “desonesto", “desprotegido", “destravar” e "desumano" como exemplo desses sentidos.

Em relação ao prefixo “dis”, o autor disponibiliza apenas duas acepções (movimento para diversos lados e ação contrária) com os seguintes exemplos: "discordar", "discutir", "disseminar", "disjungir" e "distender". Na descrição deste prefixo, o não compromisso com a utilização de palavras transparentes para sustentar as assertivas desenvolvidas torna-se evidente.

\section{2 .}

\section{Abordagem gerativa: o prefixo como seleção categorial e semântica}

Em relação aos processos de prefixação, diferentemente do que propõe a tradição gramatical normativa, Silva \& Mioto (2009) estabelecem, em suas proposições, que os prefixos selecionam rigidamente as bases categoriais às quais irão se combinar. É importante estabelecer que essa singularidade é reconhecida como sendo uma propriedade dos sufixos. Por esse motivo, Gonçalves (2011) afirma que o sufixo "-mente" se junta apenas aos adjetivos de gênero feminino para formar advérbios. Assim, não seria possível, por exemplo, utilizar este sufixo para construir advérbios a partir de substantivos, verbos e adjetivos masculinos.

Os linguistas Silva \& Mioto formalizam sua proposição ao estabelecer que a seleção categorial do prefixo envolve necessariamente certas características semânticas da palavra base. Além disso, essa proposta se baseia nas análises de prefixos nas línguas eslavas conduzidas por Syenonius (2004). Adicionalmente, os linguistas afirmam que a hipótese de que os prefixos selecionam a base não resulta em um custo adicional ao falante uma vez que o mesmo princípio se aplica na sintaxe, uma vez que um verbo seleciona seus argumentos.

Segundo Silva \& Mioto (2009, p. 15-17), um dos principais motivos para aderir a essa proposição seria o fato de ela evitar a ambiguidade estrutural. Para isso, utiliza-se, como exemplo, a palavra desmobilização que pode ser representada, segundo os autores, por meio de três possibilidades de processos de 
derivação que assim se seguem: “[[[des[mobil]]iza]ção]”;

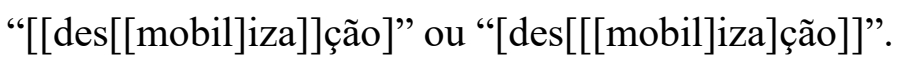

Os autores afirmam que, pelo fato de o prefixo des- ser altamente produtivo em verbos, como em: desfazer, desconectar, descombinar, desinfetar, destelhar, deconsiderar etc. e "desmobilização" possuir a noção semântica de reversão de uma ação, o correto seria afirmar que o processo de estruturação adequado seria o proposto na segunda configuração supracitada. No entanto, como o prefixo "des-" também é produtivo em adjetivos no Português, como nos exemplos: desnecessário, desleal, deselegante, desigual etc., é possível compreender que o processo derivacional em "A" também seria possível. Dessa forma, para afirmar a validade de sua proposta de seleção categorial, os linguistas propõem que há dois prefixos homônimos na Língua Portuguesa.

Nas palavras de Silva \& Mioto (op. Cit., p. 17) caso um prefixo se combine a um verbo, seu sentido seria uma reversão de processo; contudo, se a adjunção ocorrer com um adjetivo, o sentido é um tipo de negação. Dessa maneira, há vocábulos como "desleal", que possui o significado próximo a "sem lealdade", porém em “desfazer" não há a possibilidade de interpretar esta palavra como "sem (não) fazer". Por este motivo, os linguistas afirmam que é possível hipotetizar a existência de pelo menos dois prefixos "des-" e, por esta razão, deveria haver duas entradas para ele no dicionário de morfema no Português. O primeiro seleciona verbos e significa uma reversão e o segundo significa negação, mas, neste caso, se adjunge a adjetivos.

Em se tratando do argumento semântico, De Bona \& Ribeiro (2018) afirmam que a categorização semântica aparentemente encontra respaldo no Português uma vez que o prefixo des- se adjunge a verbos que possuam uma semântica de processo, como em “desfazer", “desnivelar”, “desconstruir", “desligar" e "desarrumar". Nesses casos, a noção de reversão de processo é clara. No entanto, o mesmo não ocorre com verbos que não expressam processos, o que impossibilita a formação de verbos como "desmorrer", "deschegar", “desnadar", "desandar"1 etc. assim, a inviabilidade de usar o prefixo des- realmente é

\footnotetext{
${ }^{1}$ Quanto a esta afirmação, discordamos tanto de De Bona \& Ribeiro (2018), uma vez que o verbo "desandar" é de uso consagrado no português brasileiro contemporâneo. A fim de justificar nossa posição, baseamo-nos na definição deste vocábulo proposta por Fernandes (1972, p. 196) que
} 
determinada pela incompatibilidade semântica com a base verbal. Porém, é importante estabelecer que, ainda assim, a proposta de Silva \& Mioto (2009) ainda não está apta para proporcionar uma resposta definitiva quanto a este problema uma vez que De Bona \& Ribeiro (2018, p. 615) examinam que há verbos como "gostar", "crer", "amar"2 que licenciam formações com prefixo "des-" e, quando isso ocorre, o sentido estabelecido não é uma reversão de processo e sim uma negação. Se houver a adoção plena das propostas de Silva \& Mioto, como haveríamos de analisar estas formações?

De Bona \& Ribeiro viabilizam uma outra alternativa a qual estabelece que os verbos de estados e alguns verbos de ação disparam a mesma noção semântica que um adjetivo, que seria uma negação. Por esta razão, não é válido pressupor que as noções de reversões e negações estão automaticamente associadas às categorias dos verbos e dos adjetivos, respectivamente, uma vez que é necessário, primeiramente, analisar a semântica da palavra base. Com base nestas proposições, os linguistas De Bona \& Ribeiro determinam que a postulação da existência de dois prefixos "des-" homófonos perde a credibilidade visto que o sentido do prefixo não é necessariamente diferente quando a categoria gramatical não é a mesma.

Ainda em uma perspectiva gerativa no que diz respeito à formação de palavras, Oliveira (2004 e 2009) propõe, assim como Silva e Mioto, que o prefixo "des-" seleciona semanticamente as bases a que se unem. Isso quer dizer que o sentido do prefixo é pré-determinado sistematicamente por meio da configuração morfológica da palavra a qual o afixo se adjungiu.

estabelece "Transitivo - Fazer andar para trás: "DESANDA a carruagem, e para à porta de outra hospedaria." (Camilo, Esqueleto, 196.) / Percorrer em sentido contrário: "Um pouco adiante, DESANDEI o caminho e guiei para casa." (M. Assis, Brás Cubas, 148.) "Andando e DESANDANDO um só caminho, proveito não alcança.” (Rui, Estalante clássica, 25.) [...] / Intransitivo - [...] Tornar, voltar retroceder: "Parece que chegou a DESANDAR para casa." (M. Assis, Outras relíquias, 11.)

\footnotetext{
${ }^{2}$ Também nesta situação discordamos dos exemplos viabilizados por De Bona \& Ribeiro (2018), uma vez que os verbos enumerados não só possuem sentido negativo, mas também licenciam uma interpretação reversiva, conforme pudemos analisar no dicionário eletrônico Houaiss (2001). Mais especificamente, em relação ao verbo "desgostar" são elencadas quatro acepções, das quais a segunda é descrita como "não gostar; deixar de sentir simpatia; amor por; desafeiçoar(-se), desestimar(-se); adicionalmente, "descrer" também é descrito a partir de quatro acepções, sendo a segunda "não acreditar ou deixar de acreditar" e, por fim, o verbo "desamar", de acordo com o referido dicionário, possui três acepções, sendo a primeira "deixar de amar(-se); não (se) amar".
} 
No que se refere aos dados de sua pesquisa, a linguista explica que foram listadas cinquenta e cinco palavras de bases substantivas, cinquenta e cinco de bases adjetivas e setenta de bases verbais, todas coletadas a partir de jornais, de revistas e do Dicionário Novo Aurélio (1999), porém não houve explicações sobre os procedimentos adotados para a extração de dados, nem mesmo sobre o nome e as edições dos jornais e das revistas consultadas. Além disso, não há informações se as palavras coletadas são todas transparentes para o falante do Português Brasileiro contemporâneo.

Quanto às bases substantivas, Oliveira (2004, p. 94) realiza a análise das palavras fora de seu contexto de utilização e explica que o prefixo "des-", quando acoplado a substantivos abstratos primitivos como nos pares "afeto/desafeto", "serviço/desserviço" e "fortuna/desfortuna", o sentido seria de "ausência de" ou "falta de". Caso o referido afixo esteja adjungido a substantivos derivados pelos sufixos "idade", “mento", “ão", “ção” ou "ança”, como em "desvalorização", “desaparição", “desunião", “descomplementaridade”, “dessemelhança” entre outros, o sentido passa a ser de "contrário de". Em substantivos deverbais formados por derivação sufixal zero, como nas palavras "desacordo", "descarga" "desacerto" e "desgoverno" o sentido também se mantém como "contrário de".

Por fim, a pesquisadora, com base nesta análise, propõe que a RFP do prefixo "des-" acoplado a uma base substantiva possua dois produtos "a) um substantivo derivado que significa 'ausência ou falta de X', em que X é o substantivo primitivo e b) um substantivo derivado com o sentido de 'que é o contrário de X', em que X é o substantivo deverbal.” (OLIVEIRA, 2004, p. 95).

É curioso notar que, para a autora, os substantivos derivados em "des-" nunca possuirão sentido reversativo, independentemente do seu contexto de uso, uma vez que a Regra de Formação de Palavra formalizada não prevê essa possibilidade. Como explicar, então, casos como "a desmontagem de automóveis é trabalhosa"? Seria viável interpretar "desmontagem", neste contexto, apenas como "o contrário de montar"? 


\section{3.}

\section{Além das categorias e subcategorias: o argumento interno do verbo e os traços semânticos de Lieber}

Medeiros (2010), ao abordar a descrição do prefixo “des-”, se apoia nos pressuposto da morfologia distribuída proposta por Hale (1993) e Marantz (1993 e 1997). Além disso, o linguista discorda das afirmações propostas por Silva \& Mioto de que os prefixos selecionam rigidamente as bases às quais irão se unir pelo motivo de que essa proposição aumenta o número de homônimos que, segundo os autores, não possuem relação entre si. ("des-" que atua em verbos e o outro, em adjetivos). Além disso, Medeiros explica que, em se tratando dos verbos, não necessariamente o prefixo "des-" reverte o processo, mas, na verdade, pode negar e/ou inverter um estado que é interno ao verbo.

Dessa forma, o pesquisador propõe que o prefixo supracitado dispõe de uma seleção semântica e não categorial da base. Tal afirmação implica o fato de que, segundo suas proposições, o prefixo nega ou inverte o estado referente à própria significação verbal e não ao processo associado.

Para sustentar suas afirmações, Medeiros explica que, se o prefixo "des-" em desenterrar pressupusesse a ação anterior de enterrar algo, uma frase como "o João desenterrou as raízes daquela árvore" não poderia ser aceitável em situações em que as raízes nunca foram enterradas.

Sua argumentação se desenvolve sob esta linha de raciocínio e, a fim de demonstrar o potencial geral de suas propostas, Medeiros estabelece outros exemplos, como no caso dos verbos "descolar", "desacordar", “desorganizar", "descolorido" que não pressupõem que o evento a que se referem tenha ocorrido anteriormente uma vez que "descolar" não pressupõe que algo tenha sido colado, por exemplo. Assim, Medeiros (p. 98) estabelece que "É tarefa simples imaginar contextos em que usamos os verbos prefixados sem que o evento denotado pelo verbo de base tenha necessariamente ocorrido."

Objetivando enfatizar suas proposições de que o prefixo "des-“ não nega ou inverte um processo, Medeiros explica que verbos típicos que denotam atividade não o aceitam, ainda que haja um ponto final para as ações executadas. 
Por esta razão, não há possibilidade de construir verbos como ${ }^{*}$ descorrer $^{3}$ (dois metros), *destrabalhar (até o fim de semana), *desdançar (o música), *despular (a cerca), *desgritar (o seu nome) *desfalar (a promessa) e assim por diante. "Tais verbos não implicam, pelo menos não de maneira óbvia, mudança de estado de seu participante (agente), e, portanto, não servem de base para uma derivação que envolva tal prefixo.” (op. Cit, p. 98)

Assim, Medeiros estabelece um sentido único para o prefixo que se refere ao estado interno do verbo. Em se tratando dos adjetivos, o pesquisador afirma que, por terem a função de ligar uma entidade a um estado de valor de verdade, aceitam prefixação com des-. "Alguns nomes de estado, em particular muitos nomes de estados psicológicos (afeto, amor, esperança, alento, ânimo, estímulo, temor, etc.), também aceitam a prefixação.” (op. Cit., 2010, p. 116).

Também é importante salientar que os adjetivos e nomes com o prefixo des, ao contrário do que ocorria com os verbos, não pressupõem o estado denotado pela raiz. Por exemplo, alguém pode estar descontente com alguma coisa sem ter estado contente com ela antes. Isso reforça a ideia de que a pressuposição do estado é uma particularidade semântica dos verbos assim prefixados, não é algo universalmente associado ao prefixo. Como aos adjetivos e nomes discutidos acima não há processo associado, não há um estado inicial a ser desfeito, e, portanto, não há pressuposição de existência de um estado qualquer.

Por fim, o pesquisador postula que, pelo fato de o nó semântico de negação envolver uma noção de estado, espera-se não encontrar o prefixo des- em nomes de eventos como trabalho, dança, pulo etc. Também não será utilizado em nomes que designam seres e entidades no mundo como cachorro, gato, pedra ${ }^{4}$, entre outros.

\footnotetext{
${ }^{3} \mathrm{O}$ uso do asterisco $(*)$ é utilizado para indicar a ocorrência de uma palavra e/ou frase agramatical, ou seja, que não é considerada aceita por nenhum membro da comunidade linguística de um povo, independente de seu grau de instrução ou procedência geográfica.

${ }^{4}$ Acreditamos que essa proposição é passível de ser contestada, uma vez que há registros de utilização de palavras como "desprefeito" e "despresidente" que seriam justamente a adjunção do prefixo "des-" a palavras de que designam seres e entidades no mundo biofísico. Os exemplos podem ser encontrados, respectivamente, em:
} 
Ainda em relação ao prefixo “des-”, De Bona \& Ribeiro (2018) se baseiam nas proposições de traços semânticos desenvolvidos por Lieber (2004) para proceder a análise dos afixos. Os seis traços semânticos propostos possuem valores binários, podendo ser positivos ou negativos. A função principal desses traços, de acordo com os linguistas, é "distinguir as principais categorias ontológicas dos lexemas, assim como conceitos básicos de tempo, espaço e quantidade" (p. 621). Além disso, dependendo do item lexical, os traços podem estar presentes ou ausentes da estrutura semântica, levando em consideração a relevância de seu conteúdo para a descrição do vocábulo analisado.

Dentre os seis traços elencados, o de maior importância é o "Location" (doravante "Loc") visto que, em itens lexicais cujas noções de tempo e espaço são relevantes, terá este traço positivo; porém, caso estas noções sejam irrelevantes, o referido traço será negativo.

De Bona \& Ribeiro, com base nos pressuposto de Lieber (2004), propõem que a ausência do traço "Loc" sinaliza a ideia de falta ou privação na caracterização de determinados verbos, nomes e substantivos que possuem sentido negativo a partir dos afixos derivacionais. Além disso, é interessante notar que as nuances de significado levemente distintas, como privação, negação contrária, negação contraditória e reversibilidade, já são acionadas a partir do traço [-Loc] quando entram em contato com a palavra base a que se adjungem. Dessa forma, "A semântica e o tipo de base ao qual o prefixo vai se adjungir apresentam, pois, um papel fundamental, já que a semântica de cada afixo só poderá ser determinada quando este estiver em contato com sua base" (p. 625)

Dessa maneira, reconhece-se a polissemia dos afixos. No entanto, é argumentado, segundo Lieber (2004), que não há a necessidade de distinguir entre os tipos de negação visto que apenas durante o uso do prefixo em uma base é que sua semântica será denotada. Assim, pode-se afirmar que o prefixo "des" possui diferentes significados, mas é a base selecionada que será responsável por acionar o sentido demandado. Logo, “A interpretação dos vários itens lexicais prefixados negativamente vai depender das propriedades do prefixo juntamente com a

<https://twitter.com/caleromarcelo/status/1188811932154978304> Acesso em 08 de janeiro de 2020 e <https://dandomilhoaospombos.wordpress.com/2019/03/29/bolsonaro-o-despresidente-dobrasil/> Acesso em 08 de janeiro de 2020. 
natureza semântica do item lexical e de esta poder ou não ser analisada como graduável. Esses afixos, então, podem ser considerados exemplos de uma polissemia construtiva.” (DE BONA \& RIBEIRO, 2018, p. 625)

Adicionalmente, é proposto por De Bona (2014) que o prefixo "des-" possui apenas a semântica reversativa como produtiva no Português atual; consequentemente, os traços semânticos de negação de um estado deixaram de ser produtivos. A fim de sustentar suas propostas, foi realizada uma pesquisa diacrônica com os itens lexicais transparentes precedidos pelo prefixo em questão com o objetivo de atestar que as construções cujos sentidos são de negação tratam-se de palavras com entradas muito antigas no vernáculo da Língua Portuguesa, ao passo que os que possuem a semântica de reversão da trajetória de um estado permanecem sendo construídos ainda no Português contemporâneo.

Em relação aos substantivos, $86 \%$ dos que foram analisados são deverbais e foram elencados a partir do dicionário Houaiss 2009. Como resultado, constatou-se que substantivos como "desamor", "desarmonia", "desatenção", "descaso", etc., palavras estas cujo prefixo "des-" denota semântica de negação, tiveram sua incorporação no vernáculo do Português, respectivamente, em s. XIII, 1844, 1639-1696, 1817-1819 e assim por diante.

Em se tratando dos adjetivos, houve o mesmo sistema de coleta de dados e 81.2\% destes são deverbais. Como forma de exemplificação, De Bona \& Ribeiro (2018) estabelecem as palavras: "desamigo", "descontente", "deselegante", “desigual” etc. cujas incorporações no léxico da língua ocorreram em s. XIII, s. XV, 1899 e s. XIII.

Por fim, também foram elencados verbos utilizando a mesma metodologia de coleta anteriormente citada. Dessa maneira foram estabelecidos os seguintes exemplos: "desamar", “desconhecer", “descrer" e "deslembrar" e suas respectivas inclusões lexicais se deram no século XIII e a última no século XV.

Finalmente, De Bona \& Ribeiro (2018), objetivando decretar a improdutividade semântica negativa do prefixo "des-", recorrem ao corpus de neologismos sobre o afixo em questão desenvolvido por Santos (2016). Dessa forma, as novas criações lexicais, verbais, substantivas e adjetivas, precedidas por “des-”, em sua maioria, carregam a noção semântica de retroação de um estado ou ação, tendo, por exemplo, palavras como: desinvadir (1996), desacusar (1996), 
desincentivar (2004), deslavagem (1996), desconversa (1994), desarmador (sem registro), desarquivador (sem registro) etc.

Embora as informações supracitadas apontem para uma possível aparente improdutividade da semântica negativa do prefixo "des-", o próprio corpus desenvolvido por Santos (2016) aponta neologismos igualmente atuais utilizandose do prefixo "des-" com a semântica negativa, como nos exemplos: "desacontecimento" (1996), “desimportância" (1994), “desrelação" (1998), “despoliciado" (1997), “descomandado" (1999). No entanto, Santos (2016) afirma que tais formações são "esporádicas" em todo o corpus. Contudo, seria adequado estabelecer que o referido afixo não mais possua sentido negativo pelo fato de, aparentemente, formar poucas palavras “contemporâneas” com essa acepção?

\section{4 .}

\section{Primeiros olhares para o prefixo em seu contexto de uso}

Em sua pesquisa, Dolinski (1993) compreende que o prefixo “des" possui diversos aspectos de negação. Por este motivo, o pesquisador se atenta para a importância de analisar a palavra em seu contexto, porém, mesmo reconhecendo esta necessidade, não houve menção ou explicação detalhada de como foi feita a extração das palavras utilizadas para a análise; antes o linguista limitou-se a informar que coletou palavras de jornais, principalmente as não dicionarizadas no Dicionário Aurélio.

Dolinski (1993, p. 42-43) desenvolveu uma seção em que trata dos sentidos do prefixo "des" em substantivos derivados. Assim, nas configurações "DES- + base substantiva em -mento" e "DES- + base substantiva em -ção", o linguista chama atenção para o fato de que, embora os sufixos possuam significados diferentes, às vezes sua diferenciação é imprecisa uma vez que, de acordo com suas observações, a escolha entre um sufixo ou outro na formação de palavras depende da regulagem fonológica, pois a tendência do falante seria a de evitar repetição do mesmo fonema já existente na palavra base. Assim, por exemplo, os verbos "passar" e "alisar" tem como nominalização os produtos "passamento" e "alisamento" em vez de "passação" e "alisação". Contudo, 
mesmo que a escolha entre estes sufixos seja, na maioria dos casos, fonologicamente motivada, há formas prefixadas que coexistem como em "despovoação" e "despovoamento" ou "descongelação" e "descongelamento". Para a resolução destes casos, Dolinski se baseia em Monteiro (1987) ao explicar que os nomes abstratos em "ção" indicam uma ação ao passo que os formados em "mento" são relacionados ao resultado de uma ação.

Em relação ao sentido dos substantivos derivados em "mento", Dolinski propõe o sentido de reversão em formações parassintéticas, como em "desabastecimento", “desengavetamento" e "desatrelamento". Porém, ele reconhece que há possíveis exceções como em "desfuncionamento", que não é a reversão do que funciona, mas "parar de funcionar". Esta formação possui ainda outros sentidos, sendo eles "falta de", como em "desalinhamento"; "mudança de estado", como em "desaquecimento" e "o prefixo 'des-' com significado de 'não", como em "desbalanceamento".

Dolinski também detalha os sentidos de formações em substantivos derivados em "ização" e "ção". Na ocorrência de "duplo sufixo", o sentido é majoritariamente de reversão como em "desburocratização", "descartorialização", "desfederalização". Contudo, em casos em que ocorre apenas o sufixo "ção", os sentidos podem ser múltiplos, como a palavra "descoordenação", a qual afirma ter sentido de "privação e/ou falta de" (p.50); "ato ou efeito de cessar uma ação", como em "descomplicação" e o prefixo nesta formação também pode possuir sentido de "má ou mau", como em "desinformação" e "desadministração". Por fim, o linguista não proporciona maiores detalhes para o sentido do prefixo "des" em formações com o sufixo "agem" e limita-se a explicar que ele pode possuir sentido irônico e estilístico em palavras como "desaprendizagem".

Adiante, o linguista (op. Cit. 55-65) trata do sentido do prefixo "des" em substantivos não sufixados e conclui que há a possibilidade de ocorrência de muitos sentidos, sendo eles "falta ou ausência", como em: "descritério", "deseconomia", "desesperança" e "desincentivo"; "reversão" ou "desbloqueio", como em "desconstrucionismo"; "mal, mau ou valor depreciativo": "desprefeito", "desserviço", "despudor"; "reforçativo ou pleonástico": "desinfelicidade" e "desinquietação" e, finalmente, "perda de, cessação de estado ou situação": “desconversa" e "desengano". 
Por fim, é importante destacar que Dolinski reconhece a possibilidade de bidirecionalidade das formações nominais, como na palavra "desempoeiramento", que tanto pode ser o ato ou efeito de "desempoeirar", porém ele não explica como se deveria fazer a análise deste item lexical nem leva em conta os elementos (con)textuais como uma possibilidade de determinar qual seria a construção da palavra. Antes, o linguista simplesmente determina que, para casos como estes, apenas se deve levar em conta "a base que está na mente do falante" (op. cit. p. 44).

Ainda em uma perspectiva de privilegiar os elementos de uso para a compreensão do sentido do prefixo, Schneider \& Bidarra (2009) posicionam-se defendendo que o prefixo "des" deva ser analisado à luz de seu contexto de utilização. Para isso, os pesquisadores consultaram a versão online do jornal "Observatório da Imprensa" a fim de realizar a coleta de dados. Também foi explicado que foram coletados 172 recortes contendo palavras transparentes prefixadas em “des". Dessa forma, de acordo com os linguistas, vocábulos como “destacar" e "destruir" não fazem parte de seus dados, pois, no momento sincrônico da língua, as palavras "tacar" e "truir" não são bases possuidoras de significados.

Schneider \& Bidarra elencaram sete sentidos para o afixo em questão, sendo eles "1 - Negatividade”, "2 - Positividade”, 3 - "Ação contrária”, 4 "Aumento, intensidade", 5 - "separação", 6 - "transformação" e 7 - "falta de harmonia”. No entanto, em relação às bases substantivas, apenas o primeiro, o quinto e o sétimo sentidos foram encontrados.

Em relação ao sentido de negatividade, os pesquisadores explicam que ele é o mais dominante de todas as ocorrências analisadas e a função deste sentido é "trazer para o plano da palavra derivada algo que deixa de estar presente no significado da palavra-base" (op. cit. p.74-75) e utiliza, como exemplo de sentido negativo, a palavra "desinformação" na frase "a censura pode resultar em rumores e desinformação nas ruas". Assim, é estabelecido que o prefixo nesta construção "Indica um estado de quem tem pouca ou nenhuma informação sobre algum assunto. Ou ainda, sugere uma informação propositadamente errônea. Isso certamente se revela um dano ou prejuízo e, por isso, o des- imprime um sentido negativo de perda à qual se coliga." (SCHNEIDER \& BIDARRA, 2009, p. 75). 
Ainda sobre os sentidos do prefixo ocorridos em bases substantivas, os autores explicam que o sentido de separação é altamente polissêmico e cunharam dois tipos. O primeiro seria a separação em substâncias concretas e o segundo, a separação em elementos abstratos. A fim de sustentar sua proposição, foram disponibilizados dois contextos de uso, sendo eles:

1 - "Um exemplo desse descolamento são os resultados de uma pesquisa mundial sobre liberdade de imprensa divulgada no início de dezembro."

2 - "não é possível mais conceber a TV ou qualquer outra produção de mídia desatrelada da educação e da promoção da cultura."

Assim, na primeira ocorrência do prefixo "des", Schneider e Bidarra afirmam que a separação em questão envolve estruturas físicas, de constituição concreta. Contudo, na segunda ocorrência, ocorre uma forma de afastamento, uma ruptura de caráter abstrato, porém "a partir de uma ideia mais particularizada" (op. cit. p. 80).

O último sentido presente em construções substantivas seria "falta de harmonia", cujo significado também pode expressar "instabilidade". Assim, as palavras "desequilíbrio", "desaprovação" e semelhantes denotam este sentido. Além disso, foram utilizados os seguintes contextos para justificar esta classificação:

1 - "Na retaguarda, nas equipes técnicas e de produção, também se repete o desequilíbrio observado na tela"

2 - “a desproporção entre conteúdo e publicidade verifica-se também em outros veículos de comunicação de massa".

3 - "O DVD intitulado Tropa de Elite 3, que se acha há muito tempo nas ruas do Rio, poderia ser noticiado apenas como sintoma de dois fatos sociais maiores, para os quais só agora o poder público parece estar acordando: (1) o agravamento da violência urbana pela progressiva falta de controle sobre o tráfico de drogas e os assaltos; (2) a transformação desse descontrole em espetáculo".

Os autores, por fim, enfatizam a autonomia do sentido "falta de harmonia" como não sendo um mero caso de negação ao explicar que, embora estas ocorrências sejam casos de negatividade, elas claramente são mais específicas que uma simples negação. Além disso, também se baseiam nos pressupostos de Câmara Jr. (1971, p. 45) de que o sentido de um vocábulo não necessariamente é a 
soma exata de seus constituintes, porém os linguistas reconhecem que, "muitas vezes, são pequenas as fronteiras de delimitação entre uma categoria semântica e outra" (SCHNEIDER \& BIRRADA, 2009, p. 82). 
3.

\section{Pressupostos teóricos e metodologia}

A primeira parte deste capítulo, que é referente aos pressupostos teóricos, dividese em três seções. Na primeira, exploraremos as principais propostas da Linguística Cognitiva para os estudos da linguagem. Dessa forma, trataremos de seu compromisso interdisciplinar com outros campos da ciência e do foco na língua em uso; exporemos as noções de categorias prototípicas e radiais e, posteriormente, descreveremos o tratamento viabilizado pela abordagem cognitivista para a compreensão do sentido; assim, trabalharemos com as noções de frames, domínios cognitivos e metáfora. Posteriormente, discutiremos a insuficiência das noções de regras de formações de palavras uma vez que este aporte não consegue dar conta de muitos tipos de criações vocabulares, o que nos leva a adotar os princípios de regras analógicas para muitos casos de palavras nãodicionarizadas. Por fim, apresentaremos a noção de nominalização que utilizamos neste trabalho, a qual consiste na junção do tratamento morfológico proporcionado por Basílio (1980) ao semântico proposto por Langacker (1991). Na segunda parte deste capítulo, que é referente à metodologia, descreveremos os processos metodológicos adotados nesta pesquisa. Assim, estabelecemos três subseções para este fim. Inicialmente, tratamos da descrição do corpus selecionado, bem como a justificativa de sua escolha, além de especificar as condições de extração das palavras utilizadas como dados. Adiante, o segmento posterior explica o desenvolvimento das acepções que foram estabelecidas para o prefixo "des-" ao passo que a última seção descreve como ocorre a análise vocabular que empregamos no trabalho.

\section{1.}

\section{Fundamentos teóricos}




\subsection{1.}

\section{Princípios fundamentais da Linguística Cognitiva}

A partir de uma série de insatisfações com as proposições referentes aos estudos da linguagem, até então estabelecidas pelo Gerativismo, destaca-se a pouca importância dada à semântica em favor da sintaxe (LANGACKER, 2009). Houve a necessidade da criação de um novo paradigma de investigação dos estudos linguísticos que privilegiasse os aspectos da linguagem que não recebiam devida atenção na abordagem anterior (LOURENÇO, 2010).

Uma das principais contribuições advindas da Linguística Cognitiva para a linguagem se baseia no entendimento de que o empreendimento dos estudos linguísticos não deve ser uma tarefa alheia a outros campos da ciência, principalmente da antropologia e da psicologia, nas quais se destacam as contribuições de Brent Berlin e Eleanor Rosch, respectivamente. Essa posição vai de encontro ao clássico labor de Saussure (2012) em estabelecer a Linguística como ciência autônoma e livre da necessidade de contato com outras ciências para que pudesse conduzir seus estudos e suas investigações.

Dentre as propostas estabelecidas pela perspectiva da Linguística Cognitiva, destacamos, nos termos de Bybee (2010), a base experiencialista para a aquisição e uso da linguagem. Essa proposição determina que o conhecimento linguístico de um falante não se origina apenas a partir de um dispositivo único, autônomo e desenvolvido especialmente para esta finalidade.

A partir do pressuposto da existência de uma base experiencial da linguagem, estabeleceu-se o princípio da "mente corporificada" (JOHNSON, 1990) que determina que os usos da língua de um falante surgem a partir de suas experiências corpóreas, de maneira que seus conceitos são formados a partir do contato físico para depois ocorrer a abstração. Assim, a cognição não é alheia nem separada das interações culturais e pragmáticas (CROFT \& CRUISE, 2004). Dessa maneira, Silva (1997) estabelece que a sintaxe e a semântica são produtos conceptualizados pelo falante e destaca a importância da categorização durante este processo.

$\mathrm{O}$ ato de categorizar está intimamente ligado à capacidade de observação e determinação das características que melhor definem um certo conjunto de seres, 
objetos, ações e assim subsequentemente. Ferrari (2018) explica que é importante categorizar a fim de não sobrecarregar a memória do falante. Assim, Ferrari (op. cit.) exemplifica que, ao analisar que um animal possui bico, asas, penas e pode voar, como no caso de uma águia ou um sabiá, o colocamos na categoria de aves. É importante destacar que, de acordo com Smith \& Medin (1981), o ato de categorizar é uma preocupação existente desde a Era Clássica, cujo principal pensamento é o de Aristóteles ao afirmar que todos os membros de uma categoria são definidos a partir apenas das propriedades em comum compartilhadas por todos os seus membros. Como consequência, nenhum membro é considerado melhor exemplo de sua categoria que os demais. No entanto, a principal contribuição da Linguística Cognitiva, a partir dos estudos de Psicologia Experimental propostos por Hull (1920) e Rosch (1973, 1975 e 1978), é demonstrar a insuficiência da abordagem clássica para a compreensão da categorização.

De acordo com os pressupostos da Linguística Cognitiva, a categorização não se consiste apenas em elencar semelhanças bem delimitadas entre entidades para formar um grupo uma vez que há a possibilidade de alguns membros não apresentarem todas as propriedades que determinam um grupo. Assim, desenvolveu-se a noção de protótipos para se referir aos membros do grupo que apresentam a maior quantidade de características determinadas pela categoria e os radiais que, diferentemente dos anteriores, embora façam parte da categoria, não apresentam todas as características.

Em adição, Ferrari também destaca que a categorização é, sobretudo, um fenômeno contextual e de natureza cultural. A fim de esclarecer essa proposição, a linguista explica que a depender do contexto de interação, como em "eles decidiram enfeitar a árvore do jardim para o Natal" e "a brisa balançava as árvores na orla baiana", embora a palavra "árvore" seja a mesma, o referente não é uma vez que no primeiro enunciado o sentido evocado é um pinheiro e, no segundo, um coqueiro. Essa conceituação de categorização proposta pela Linguística Cognitiva demonstra seu comprometimento com a compreensão do sentido em uma perspectiva não-objetivista.

O tratamento do sentido na abordagem cognitiva é bem diferente do que, até então, era proporcionado pela Linguística Gerativa uma vez que, de acordo 
com Fodor \& Katz (1964), acreditava ser possível determinar o sentido da palavra a partir da análise de seus traços semânticos binários que, consequentemente, poderiam ser positivos ou negativos. Assim, por exemplo, a palavra HOMEM é formada pelos traços semânticos [+HUMANO], [+MASCULINO] e [+ADULTO] ao passo que a palavra MENINO seria constituída pelos traços [+HUMANO], [+MASCULINO] e [-ADULTO]. Assim, a diferença entre os dois vocábulos supracitados se daria por meio da existência do terceiro traço semântico na primeira palavra e de sua inexistência na segunda.

A visão objetivista sobre o sentido foi duramente criticada por Fillmore (1982) ao contrastar as palavras "solteirão"5 e "Papa". Ambas, a princípio, seriam formadas por [+HUMANO], [+MASCULINO], [+ADULTO] e [-CASADO]. No entanto, seria adequado conceituar todo "solteirão" como "papa" ou vice versa? A partir deste exemplo, Fillmore não só demonstra que o sentido não é alcançado de forma objetiva apenas se utilizando de traços semânticos binários, mas também que o sentido é socialmente construído uma vez que esta palavra só poderia ser utilizada "por pessoas em uma sociedade em que certas expectativas sobre casamento se mantêm [tal como a idade certa para se casar]. Por isso, o nome não é normalmente usado para descrever o Papa, ou um garoto abandonado na floresta que tenha atingido a maturidade sem contato com as sociedades" (FERRARI, 2018, p. 54).

Ainda em relação ao sentido em uma perspectiva da Linguística Cognitiva, Fillmore (op. cit.) desenvolve o conceito de Frames $^{6}$, que se refere a um conhecimento desenvolvido com base na experiência física e cultural do falante e estruturado em sua cognição. Dessa maneira, as palavras não possuem sentidos autônomos, antes eles são acessados a depender do frame que é ativado no momento da interação. Assim, os verbos "ensinar" e "aprender" ativariam os frames de "evento de sala de aula". A noção de frame também é utilizada para descrever a diferença de palavras a depender do contexto social em que é empregada. Assim, a palavra "juiz" pode ativar um sentido quando ativar o frame

\footnotetext{
${ }^{5}$ A palavra utilizada em língua inglesa é Bachelor.

${ }^{6} \mathrm{O}$ termo é traduzido em algumas pesquisas no Brasil como "enquadre" ou "moldura"; no entanto, decidimos optar por manter a nomenclatura original por acreditarmos ser o mais adequado.
} 
de "evento futebolístico" e outro caso ative o de "evento de julgamento em tribunal".

A Linguística Cognitiva também desenvolve suas proposições sobre semântica a partir da noção de domínios cognitivos (LANGACKER, 1987). Sob esta perspectiva, um conceito não possui sua existência de forma autônoma do aparato cognitivo do falante. Na verdade, ao se referir a um sentido, há a ativação de determinados domínios em detrimento de outros. Langacker (1991) exemplifica esta propriedade ao explicar que o conceito de "dedo" é diretamente ligado a conceptualização de "mão" e que também pode conceptualizar, até mesmo, o conceito de "braço", mas é inegável que, ao se referir à conceituação de "dedo", haverá a ativação de "mão" mais rapidamente do que a de todo o "corpo humano". Adicionalmente, as metáforas também recebem especial atenção nesta abordagem dos estudos linguísticos visto que Lakoff \& Johnson (2002) postulam que as metáforas são dispositivos conceptuais, presentes na vida cotidiana, relevantes na construção de sentidos uma vez que elas são responsáveis por revelar a forma como o falante reconhece e categoriza o mundo em que vive, podendo utilizar seu aparato cognitivo para compreender uma "discussão" como "guerra", pois é necessário que haja um vitorioso e outro derrotado, ou, até mesmo, o "tempo" como "dinheiro", devido a sua importância e a incapacidade humana de criá-lo (op. cit., p. 49-50).

\subsection{2.}

\section{Regras analógicas: a possibilidade de análise de casos de baixa frequência}

A Linguística Gerativa proporcionou, e ainda proporciona, grandes contribuições para os estudos do léxico uma vez que a abordagem estruturalista dos estudos morfológicos apenas se importava com a análise de palavras já existentes no léxico de uma língua, além de que sua finalidade se resumia a segmentar as palavras nas menores unidades indivisíveis dotadas de sentido, 
chamadas de morfema, termo fundamental no estruturalismo americano (TRASK, 2006).

Em 1970, com a publicação do artigo de Noam Chomsky intitulado "Remarks on nominalization", os estudos lexicais passam a possuir autonomia dos estudos sintáticos. Assim, os problemas do léxico devem ser resolvidos a partir do mesmo. Dessa maneira, estabeleceu-se a necessidade de desenvolver regras generalistas que dessem conta dos processos de formações de palavras.

A essência da hipótese lexicalista e da maioria dos mais recentes trabalhos em sintaxe se baseia na hipótese de que a estrutura interna das palavras não é estabelecida por princípios sintáticos, nem mesmo acessível a esses princípios [...]. Do ponto de vista da sintaxe, as estruturas produzidas no léxico são essencialmente opacas: elas podem ter estrutura interna, mas essa estrutura não está sujeita à manipulação ou competência das regras da sintaxe, que tratam os itens lexicais como unidades integrais, atômicas. A essência da hipótese lexicalista, sob esse aspecto, está representada pela separação entre os componentes sintáticos e lexicais (ANDERSON, 1982, p. 591).

Adicionalmente, o interesse do Gerativismo não se volta apenas para as palavras já existentes no léxico de um falante, mas também naquelas que podem vir a existir por meio da aplicação das chamadas Regras de Formações de Palavras (RFP's), que seriam capazes de prever formações possíveis a partir de outras palavras já existentes, como no caso do item lexical "vendedor", que é desenvolvido por meio da adição do sufixo ao verbo, constituindo a estrutura $\left[[\text { vende }]_{\mathrm{v}}-\text { dor }\right]_{\mathrm{s}}$. Considerando as aplicações do sufixo “-dor”, o falante da língua compreende que este afixo apenas se adjunge a verbos e seu produto sempre resultará em um substantivo, como em "comprador", "entregador", "montador".

A apreensão das RFP's, por parte do falante da língua, fará com que ele consiga aplicá-las na formação de novas palavras ainda não existentes no léxico, como no caso de "apelidador", "fabricador", entre outros. Por este motivo, Basílio (1980, p. 9) estabelece que a competência lexical de um falante nativo é constituída a partir de três capacidades básicas: “a) conhecimento de uma lista de entradas lexicais; b) o conhecimento da estrutura interna dos itens lexicais, assim como relações entre os vários itens; c) o conhecimento subjacente à capacidade de formar entradas lexicais gramaticais novas (e, naturalmente, rejeitar as agramaticais)". 
As proposições desenvolvidas pela abordagem gerativa, embora sejam valiosas e de grande importância para os estudos lexicais, como já fora explicitado, não são capazes de dar conta de uma série de questões referentes a formações de palavras. Em relação a esta deficiência, temos a já difundida crítica à imprecisão do próprio conceito de "Regras de Formação de Palavras", pois, de acordo com Basílio (2010), é explicado que Aronoff propõe as chamadas regras regulares, as quais automaticamente pressupõem a existência de regras irregulares, o que por si só já demonstra certa incapacidade inata do conceito em lidar com todos os casos de formações de palavras. Além disso, Di Sciullo \& Williams (1987) defendem o caráter de regras morfológicas como leis, mas, ainda assim, tentam estabelecer algum tipo de paralelo com as regras sintáticas.

O conceito, portanto, está longe de ser claro na literatura. As interpretações variam desde a representação formal de um processo determinístico, que se aplica automaticamente, o que pode ser mais adequado para a flexão, mas traz sérios inconvenientes para a morfologia derivacional; até a noção de que as regras de formação de palavras representam generalizações indutivas (Anderson, 1992), totalmente contrária à perspectiva teórica do gerativismo. Naturalmente, a acepção prescritiva do termo 'regra', fundamental na gramática normativa, não ajuda a esclarecer o problema deste conceito e tudo que dele decorre na literatura gerativista sobre formação de palavras. (BASÍLIO, 2010, p. 3)

Além disso, a imprecisão da concepção do que seriam de fato as RFP's torna o próprio conceito de produtividade confuso e de difícil compreensão uma vez que, na literatura gerativa, não há nenhuma critério que estabeleça o que faz uma regra ser ou não produtiva, conforme já aponta Bybee (1985) ao afirmar que, nesta abordagem, uma regra que tenha como resultado 3 produtos possui o mesmo tratamento que outras que resultam em 30, 300 ou 3000 produtos.

Tomando como base Basílio (1997), aderimos ao princípio de regras analógicas, no sentido da analogia proporcional proposta por Saussure (1916) por acreditarmos que, por meio deste aparato, será possível dar conta de formações não necessariamente esperadas na língua e de pouca frequência ou, até mesmo, de uma utilização única.

Basílio explica que pode haver objeções quanto à utilização do princípio de analogia uma vez que, assim como as RFP's, esse mecanismo se propõe a 
explicar a construção de itens lexicais existentes no léxico e dos hipotéticos. Assim, em outros termos, "qualquer produto de uma RFP poderia também ser analisado como formação analógica. Mas seria verdadeiro o reverso? Ou seja, toda formação analógica pode ser analisada como produto de uma RFP?" (op. Cit. p. 10).

Com essa proposição, Basílio toca o ponto nevrálgico da insuficiência das RFP's para a análise dos itens lexicais, sobretudo os que possuem baixa frequência. Por esse motivo, a linguista indaga se o par "acrescer/acréscimo" seria o suficiente para estabelecer, por exemplo, uma regra de adição de sufixo "-imo" a verbos. Ou se seria necessário possuir maior números de ocorrências para garantir o status de regra, como nos pares "terra/terrestre" e "pé/pedestre". As indagações continuam e Basílio questiona, ainda, se os produtos destas regras deveriam ser mais transparentes, como em "rocha/rochedo" e "árvore/arvoredo". Se este for o caso, existe, então, a RFP adiciona o sufixo “-edo"? Além disso, seria esta mesma regra que atua nas construções "brincar/brinquedo" e "folgar/folguedo"? "São perguntas difíceis de responder de uma maneira bem fundamentada. Esta questão nos leva, no fundo, a perguntar o que é, exatamente, uma Regra quando falamos de Regras de Formação de Palavras.” (BASÍLIO, 1997, p. 10-11).

Em adição, uma das contribuições mais interessantes proporcionada por meio da utilização do princípio de analogia é a possibilidade de analisar palavras construídas com finalidade estilística, poética e criativa. Neste contexto, Basílio exemplifica essa propriedade ao se referir aos itens lexicais "picaz", "zombaz" e "voaz" criados por Guimarães Rosa a partir da "ressurreição" do sufixo “-az", além do igualmente interessante vocábulo "enxadachim", que claramente foi formado a partir da analogia com a palavra já existente "espadachim"; no entanto, acreditamos ser inadequado afirmar a possibilidade da criação de uma RFP's para analisar apenas este caso, o que novamente nos leva a reconhecer a superioridade dos princípios de analogia para a análise dos itens lexicais.

Por fim, esse princípio também se mostra muito proveitoso para a análise de vocábulos criados a partir das interações do dia a dia uma vez que estes geralmente podem possuir uma configuração que não seria passível de análise levando-se em conta as concepções de RFP's que temos atualmente, tal como a construção da palavra "internetário", "desvirulização", entre tantas outras. Por 
esse motivo, adotamos esse princípio para a análise das palavras nãodicionarizadas que compõem uma seção do corpus desta pesquisa.

\subsection{3.}

\section{O viés teórico da nominalização: concepção e interpretações}

A nominalização, em termos das análises propostas pelas teorias gramaticais tradicionais, como em BECHARA (2009), CUNHA \& CINTRA (2014) e ROCHA LIMA (2008), nada mais é do que o ato de derivar, a partir do verbo, uma forma substantiva, que pode ocorrer por meio da adição de diferentes sufixos, tais como "ção", "agem", “dor” e assim por diante. No entanto, para os objetivos empreendidos neste trabalho, esta descrição é simplória e pouco útil do ponto de vista prático uma vez que é incapaz de estabelecer maiores esclarecimentos, por exemplo, se as palavras coletadas no corpus desta pesquisa foram derivadas a partir da adição do prefixo a uma base verbal para, então, serem nominalizadas ou se, na verdade, a base utilizada para a configuração do vocábulo foi diretamente um nome.

Este trabalho assume os pressupostos de Basílio (1980, p 73) ao afirmar que "nominalização, como processo derivacional, é determinada por uma relação paradigmática geral entre verbos e nomes na língua." Assim, excluem-se as noções tradicionais de que o processo de nominalização seria simplesmente o ato de gerar, a partir do verbo, um nome.

Em adição, Basílio (1980) não apenas chama atenção para o fato de que os significados de qualquer forma nominalizada é semanticamente relacionada ao verbo que a originou uma vez que, em certa medida, tanto o verbo quanto o nome partilham níveis de semelhança no significado, mas também expõe o fato de que as nominalizações passam por um processo de extensão de sentido.

É importante esclarecer que este processo, embora ocorra o que a linguista nomeie de "extensão idiossincrática", que nada mais é quando uma forma nominalizada assume um sentido não-previsível como, por exemplo, o uso da nominalização "declaração" em “declaração de amor”, há também os processos de 
extensão de sentido, como a autora determina, que são "parcialmente generalizadas" (p. 75), tendo, como exemplo, a noção de "coletividade" nos termos "administração", "direção", "coordenação" etc.

Em se tratando das nominalizações, uma das contribuições mais importantes de Basílio foi ter reconhecido e proposto que este fenômeno é passível de uma interpretação dupla, "nomes podem ser interpretados num sentido nominal ou num sentido verbal, dependendo do contexto de ocorrência" (BASÍLIO, 1980, p 75). Dessa maneira, com base neste posicionamento, pode-se conceber que a compreensão adequada dos processos de formações de palavras nominalizadas não pode basear-se apenas na minuciosa análise dos morfemas constituintes do vocábulo, mas a situação de uso também precisa ser levada em consideração.

A fim de exemplificar esta proposição, a linguista expõe diversas situações de nomes que possuem dupla interpretação, como na palavra "fuga". Neste caso, são estabelecidas as seguintes frases: 1A "a fuga de João preocupou a todos" e 2A "Pedro preparou a fuga de João". Segundo a autora, na primeira sentença o nome "fuga" possui uma interpretação verbal uma vez que se pode entender, com base no contexto de uso, que seu significado seria equivalente a algo como "o ato de fugir"; porém, na segunda frase, o sentido da palavra muda e não mais possui a ideia anterior. Assim, o sentido agora em questão aproxima-se da ideia "de um plano arquitetado", o que claramente se distancia da noção clássica de ROCHA (2008) e MONTEIRO (2002) de que a nominalização seria o nome significando o ato verbal do qual foi derivado. Então, “em casos como estes, não podemos nos basear em fatores sintático-semânticos para tomar uma decisão de análise, porque um grande número de nomes nestes pares pode ter tanto uma interpretação verbal como uma interpretação nominal dependendo do contexto.” (BASÍLIO, 1980, p. 76).

Além disso, é importante enfatizar que esta propriedade não é uma situação meramente acidental e isolada uma vez que Basílio (1980) afirmou que, em sua amostragem de 305 nomes deverbais, 50\% podem ter tanto uma interpretação nominal quanto uma interpretação verbal dependendo do contexto. “os outros $50 \%$ incluem tanto nomes deverbais que só podem ser interpretados 
como verbos quanto nomes deverbais que só podem ser interpretados como nomes". (p. 81).

Esta perspectiva expõe problemas que foram aparentemente ignorados em uma modalidade de estudo mais tradicional da língua, que é a questão da direcionalidade do processo de formação de palavras, pois uma determinada nominalização, que tenha sido construída a partir de um processo estável e recorrente, pode ser interpretada de uma forma nominal ou verbal. Assim, há dúvidas se a estruturação da nominalização se deu por meio de um verbo ou um nome.

\subsubsection{1.}

\section{Nominalização em uma perspectiva cognitiva}

Uma das críticas mais usuais realizadas por Langacker (1987 \& 2008) em relação ao modelo gerativista é a presumida separação entre a sintaxe e o léxico. Seus apontamentos baseiam-se na premissa de que o usuário tem acesso a estruturas de uso por meio de ligações significativas e não necessariamente por meio de um compartimento especial e encapsulado responsável apenas para produzir e interpretar informações sintáticas, como proposto em Levelt (1993), por exemplo. Assim, “se termos como 'sujeito' e 'substantivos' são de fato universais e importantes para a gramática, a afirmação de que eles não se baseiam em uma propriedade conceptual do falante, parece um tanto quanto dúbia." (LANGACKER, 2008, p. 6).

Em termos mais específicos, Langacker explica o fenômeno da nominalização, da seguinte maneira "Semanticamente, a nominalização consiste na reificação conceitual dessa atividade [verbal], produzindo uma coisa abstrata [...] que é perfilada pelo substantivo.” (2008, p. 332, tradução nossa). Com base nesta classificação, compreende-se que a nominalização, sobretudo, é responsável pela produção da extensão do sentido verbal para uma propriedade mais abstrata.

É interessante compreender que esta concepção não se preocupa em estabelecer rigidamente as noções de direcionalidade uma vez que uma das 
propostas da gramática cognitiva, em se tratando dos "nomes", é estabelecer a ideia de que "as noções gramaticais essenciais podem ser caracterizadas semanticamente, não apenas no nível prototípico, mas também no nível esquemático" (2008, p. 103).

Propõe-se que o substantivo possui uma rede de relações significativas que, semanticamente, distingue-se do verbo por ser primariamente "um objeto físico composto de substância material", "em relação ao espaço, pensa-se em substantivo como sendo localizado em seu próprio espaço", "em relação ao tempo, por outro lado, o objeto pode persistir indefinidamente" e, por fim, "um objeto é conceptualmente autônomo, no sentido de que podemos conceptualizá-lo independentemente de sua participação em qualquer evento.” (op, cit. P. 104). Como uma consequência lógica, os substantivos que não se enquadrassem nestas proposições estariam à margem de suas propriedades prototípicas.

Em adição, é importante estabelecer que estas concepções são relevantes para este trabalho uma vez que é postulado que as nominalizações não apenas se classificam como sendo produtos abstratos abrangente da noção semântica do verbo, mas também podem passar por processos de extensão de sentidos por meio de relações metafóricas (LAKOFF \& JOHNSON, 2002). Dessa forma, Langacker (1991, p. 3) explica que nem todos os itens lexicais possuem um modelo prototípico claramente definido e estabelecido. Adicionalmente, é postulado que não é possível prever, em alguns casos, de maneira precisa, em que escala podem se dar as elaborações das extensões de sentidos.

Então, assume-se, com base no uso interacional do falante, que novos significados vão sendo evocados de acordo com as suas necessidades de comunicação, o que explicaria a multiplicidade de sentidos que as nominalizações possuem e/ou adquirem durante a situação de uso dos agentes do discurso.

\section{2.}

\section{Fundamentos metodológicos}




\subsection{1.}

\section{A construção do corpus e processo de extração de dados}

As palavras selecionadas para este corpus são substantivos derivados; portanto, adjetivos e verbos não fazem parte desta pesquisa. Além disso, expressões idiomáticas, mesmo que sejam formadas por substantivos, também não constituem nosso objeto de análise, como no caso de "cair em desgraça". A expressão exemplificada é constituída com o substantivo "desgraça”, mas, pelo fato de que seu sentido é plenamente compreendido apenas considerando toda a estrutura, deliberamos por evitar estes casos, além de haver uma extensa literatura que objetiva analisar se estas ocorrências se tratam realmente de expressões idiomáticas ou, na verdade, de uma palavra (BEBER, 2004; HALLIDAY, 2004; LIPKA, 1992), o que certamente não é objetivo de nossa pesquisa.

O substantivo, a fim de que fosse passível de análise, deveria ser transparente uma vez que adotamos um recorte contemporâneo do Português Brasileiro. É importante destacarmos que definimos o conceito de transparência utilizado neste trabalho como a interpretação da palavra prefixada de acordo com os significados projetados pelos elementos componentes da construção. Em outras palavras, um falante contemporâneo até pode reconhecer a presença do prefixo em um vocábulo, ainda que não reconheça a contribuição do prefixo para o sentido.

Adicionalmente, itens lexicais como "desenvolvimento", "descontos", "descoberta", "desgaste", "desempenho" não são de nosso interesse, pois acreditamos que este tipo de palavra pode não ser unanimemente aceito como transparentes para o falante atual, dessa maneira se estabeleceria um contínuo em que algumas palavras seriam ou não reconhecidas como derivadas, além de que estes vocábulos, a depender do contexto, podem apresentar sentidos completamente diferentes quando utilizadas sem o prefixo. Em contrapartida, palavras como "desequilíbrio", "desaceleração", "desconforto", "desinformação" e semelhantes são objetos de nossa análise, pois respeitam o critério da transparência estabelecidos a priori e, quando ocorrem sem o prefixo, mantêm o mesmo sentido que fora negado e/ou revertido pelo afixo em questão.

Os dados desta pesquisa foram gerados a partir do grande corpus eletrônico anotado NILC-SÃO CARLOS, que foi desenvolvido pelo Núcleo 
Interinstitucional de Linguística Computacional da Universidade de São Paulo em São Carlos, que pode ser acessado por meio do AC/CD, acervo disponibilizado pela Linguateca ${ }^{7}$, projeto mantido por diversas universidades portuguesas e brasileiras. Além disso, o corpus é formado por notícias jornalísticas do Jornal Folha de São Paulo entre os anos de 1994 e 1995 e de textos acadêmicos produzidos pelos alunos do referido núcleo. (NUNES et al., 1996a, 1996b).

Quanto à sintaxe de busca, utilizamos a formação "[pos="N" \& lema="des.*"]". Assim, "pos" (part of speech) refere-se à classe de palavra que decidimos procurar, que no caso seriam os substantivos, aqui representados pela letra "N" (noun). Além disso, adicionamos a informação "lema ="des*"” a qual se trata de todas as palavras do corpus iniciadas com "des" apresentadas em sua forma de singular, sem que haja, consequentemente, a listagem das variações de gênero e número. Dessa forma, por exemplo, as palavras "desagregadoras" e "desagregadores" seriam ocorrências do lema "desagregador", evitando a repetição desnecessária do mesmo radical, o que poderia atrapalhar na contagem de substantivos derivados uma vez que processos flexionais não formam novas palavras (BASÍLIO, 2004, 2007; GONÇALVES 2011).

Por fim, o uso da sintaxe resultou em 1320 substantivos iniciados com “des". No entanto, este número de ocorrências abrangia também vocábulos não transparentes. Por este motivo, procedemos para a coleta manual de todos os resultados obtidos nesta extração e estabelecemos, com base nos critérios já elucidados, 125 substantivos transparentes derivados com o prefixo "des-".

\subsection{2.}

\section{O desenvolvimento das acepções}

Para o procedimento desta análise, decidimos adotar quatro acepções para o prefixo "des-", sendo uma forma de negação, outra de oposição e duas de reversão. Assim, entendemos ser o caso de uma negação quando o prefixo "des-"

\footnotetext{
${ }^{7}$ Disponível em https://www.linguateca.pt/acesso/corpus.php?corpus=SAOCARLOS
} 
poderia ser substituído pelo advérbio de negação "não" ou semelhante sem que haja notável prejuízo em termos de sentido para a palavra em seu contexto de uso.

Além disso, é importante esclarecer que não achamos conveniente propor diferentes tipos de negações, como no caso de uma "negação por falta", uma vez que entendemos que o sentido de determinadas palavras base, quando negadas, é que passam a ideia de "falta", enquanto o prefixo "des-" continua apenas desempenhando o sentido de negação.

A fim de esclarecer nossa opção por considerar apenas o sentido da negação, propomos a estrutura "a desnutrição infantil é preocupante". Nesta frase, a palavra "desnutrição" seria compreendida, conforme já visto em alguns trabalhos analisados na revisão de literatura deste trabalho, como uma negação por falta, pois é desejado que a nutrição das crianças ocorra; contudo, advogamos que a "negação por falta" nada mais seria do que uma inferência uma vez que o verbo "nutrir", por meio do conhecimento enciclopédico do falante constituído a partir de suas experiências corpóreas (CROFT \& CRUISE, 2004), já carrega em si a informação de que essa ação/ato é importante para a existência plena do ser humano. Consequentemente, sua negação obviamente resultaria em um sentimento de falta, o que nos faz entender que o prefixo, em "desnutrição", de fato, está apenas negando ao passo que a noção de falta é ativada a partir das conceptualizações do usuário da língua, conforme propõe Langacker (1991).

Chamamos de "oposição enfática" as situações em que o prefixo "des" possui caráter expressivo, enfático e/ou estilístico. Nestas utilizações, o referido afixo passa a possuir sentido semelhante ao prefixo "anti", conforme pode ser observado em "ele presta um desserviço à população". Ao analisar esta ocorrência, não seria suficiente afirmarmos que "desserviço" deva ser compreendido simplesmente como um "não serviço", antes há, por meio do contexto, uma evidência de que se trata de um "serviço ruim" ou um "antisserviço". Dessa maneira, adotamos essa nomenclatura para dar conta das situações em que o prefixo "des-" desempenha este sentido.

No tocante às reversões, concluímos que elas podem reverter um processo ou um estado. É importante esclarecer que só será possível reconhecer de maneira eficaz qual tipo de reversão que o prefixo está desempenhando por meio da 
análise do tipo da nominalização que está sendo prefixada, que pode ser de base verbal ou nominal, além da observação do contexto de uso.

\subsection{3.}

\section{Procedimentos de análise}

Os substantivos analisados foram separados em quatro seções, considerando os seus sufixos formadores. Dessa forma, temos as seguintes subseções que constituem a análise de dados: 1 - substantivos deverbais com sufixo em "-ção"; 2 - substantivos deverbais com sufixo em "-mento"; 3 substantivos deverbais com sufixos minoritários e, por fim, 4 - substantivos deverbais sem direcionamento morfológico claro.

É importante explicar que, em relação à quarta subseção, ela é composta, como já se pode inferir, por substantivos cuja formação não se deu pela sufixação, mas por meio de uma relação virtual entre os nomes e os verbos correspondentes, nos termos de Basílio (1980). As palavras "serviço", "confiança", "equilíbrio" são exemplos dessa formação. Adicionalmente, nos reservamos a decisão de não os chamar de substantivos formados por regressão, pois há muitas discussões sobre o assunto e poucas conclusões satisfatórias. Além disso, para os objetivos desta pesquisa, não seria relevante tangenciar essas questões. Por este motivo, mantivemos a nomenclatura de substantivos deverbais como proposto em Basílio (2004).

Decidimos pela criação das subseções considerando a presença ou não dos sufixos formadores apenas por uma questão de melhor organização do trabalho. Acreditamos que a análise de cinquenta substantivos sem que houvesse nenhuma segmentação tornaria a visualização dos dados analisados menos intuitiva e mais propensa a apresentar dificuldades. Além disso, não partimos do pressuposto de que o prefixo seja categorial, nem encontramos nenhuma evidência de que os sufixos desempenhassem algum papel importante que influencie o sentido que será evocado pelo prefixo. 
Adicionalmente, antes de analisarmos o prefixo "des", entendemos ser conveniente analisar qual tipo de nominalização estamos diante, pois, dependendo de sua interpretação, a configuração morfológica da palavra será diferente. Assim, para verificar se estamos diante de uma interpretação verbal, o procedimento adotado será trocar a nominalização por uma forma verbal, geralmente o verbo no infinitivo; caso não haja um tipo de desajuste semântico para o enunciado, significa que estamos diante desta possibilidade de interpretativa. No caso de uma interpretação nominal, consequentemente, a nominalização não poderá ser trocada por uma forma verbal e também haverá casos em que a nominalização pode assumir as duas interpretação no mesmo contexto a depender da leitura do falante.

Adotamos o modelo de análise utilizado em Andrade (2006) e investigamos o sentido do prefixo "des-" na palavra, levando em consideração os seus elementos (con)textuais de uso, pois temos, como uma das hipóteses de trabalho, que apenas analisar a palavra por si só não nos revelará a polissemia existente no prefixo de maneira adequada.

Finalmente, objetivando justificar a adoção dessa modalidade analítica, propomos a frase: "a desvalorização do professor tem aumentado cada vez mais". O prefixo utilizado pode ser entendido como a reversão do estado de ser valorizado uma vez que é possível entender que o professor era valorizado e agora não é mais da mesma forma que antes ou como um caso de negação visto que a estrutura "tem aumentado cada vez mais" aponta para um processo de gradação de uma não valorização. Assim, entendemos ser pouco proveitoso o empreendimento da análise do prefixo à parte de seu contexto situacional de uso. 
4.

\section{Análise do corpus}

Neste capítulo, inicialmente, analisaremos a interpretação da nominalização prefixada pelo afixo "des", que tanto pode ser verbal, caso possua a ideia de um evento/ato/processo, ou nominal, se o sentido se referir a um estado ou ao resultado/efeito de uma ação. Utilizaremos recursos (con)textuais para justificar a possibilidade de que as duas interpretações possam ocorrer no mesmo enunciando ou para determinar uma possibilidade em detrimento da outra. Após este procedimento, contabilizaremos qual é o sentido mais frequente e o menos frequente evocado pelo prefixo "des-". Finalmente, por uma questão de organização, conforme apontamos anteriormente, as seções seguintes se dedicam a sufixos nominalizadores específicos.

\section{1.}

\section{Nominalização com formação em sufixo (-ção)}

(1) Mesmo surpresos com a morte do piloto, esses leitores souberam separar o que era boa informação de informação piegas, inútil ou apelativa, ou ainda mera desinformação.

(2) O preconceito e a desinformação sobre a doença foram temas tratados no $8^{\circ}$ Congresso Brasileiro de Hansenologia que começou anteontem em São Paulo.

Tanto no primeiro como no segundo uso da palavra "desinformação" estamos diante de uma nominalização de interpretação nominal. Na primeira situação, justificamos esta compreensão uma vez que "desinformação" seria o efeito do ato de "desinformar"; além disso, essa nominalização poderia ser substituída pela palavra "engano". Assim, concluímos que essa nominalização não possui o sentido verbal, apenas o nominal. 
$\mathrm{Na}$ segunda situação de utilização do vocábulo "desinformação", novamente tem-se o produto concreto do ato de desinformar, resultando, dessa forma, em "preconceitos sobre a doença". Adicionalmente, a referida nominalização, neste contexto, tem, por sinônimo, a palavra "equívoco". Assim, não há possibilidade para uma interpretação verbal dessa nominalização. Temos, portanto, a seguinte configuração morfológica: [des[informação]s] $]_{s}$.

Em se tratando dos sentidos do prefixo "des" nestas ocorrências, entendemos que sejam diferentes, pois em (1) há um paralelismo semântico proporcionado pela estrutura "os leitores souberam separar o que era a boa informação de [...] informação inútil [...]". Dessa forma, o afixo possui uma clara ideia de oposição ao que seria uma informação adequada, a ponto de ser adjetivada como "apelativa". Por esta razão, o prefixo "des-“", neste contexto de utilização, assemelha-se aos sentidos do prefixo "anti-“, ou seja, uma informação ruim.

$\mathrm{Na}$ segunda ocorrência da palavra "desinformação", entendemos que se trata de uma negação (por inferência, negação por falta) uma vez que a estrutura "sobre a doença" é utilizada como sendo o elemento negado pela construção "desinformação", o que dispensa a ideia de que poderia haver uma reversão. Além disso, o prefixo poderia ser trocado pelo advérbio de negação "não".

(3) Os recursos liberados pelo desarmamento poderão a curto e a longo prazos ser utilizados para reduzir os efeitos da fome e da desnutrição.

A nominalização "desnutrição" possui interpretação nominal, pois, neste contexto, ela deve ser entendida como o estado que é efeito da não ingestão de nutrientes necessários ao corpo saudável. Em relação aos aspectos (con)textuais, justificamos essa interpretação pelo fato de que a própria estrutura "reduzir os efeitos" já indica que estamos diante do resultado do processo de "desnutrir" e não dessa ação propriamente dita. Como consequência, a nominalização se dá por meio da adição do prefixo diretamente ao nome: $\left[\operatorname{des}[\text { nutrição }]_{\mathrm{s}}\right]_{\mathrm{s}}$. Em se tratando do sentido evocado pelo prefixo "des" nesta palavra, entendemos como um caso de negação (negação de falta, por inferência), pois o prefixo nega a palavra base, 
além de que ele pode simplesmente ser substituído pelo advérbio de negação "não".

(4) Os bons resultados de fevereiro, segundo o departamento técnico do banco, se devem às liquidações de vestuário, desaceleração dos preços de serviços, aluguéis e nas feiras livres.

Nesta ocorrência, "desaceleração" possui dupla interpretação. Em uma perspectiva de interpretação verbal, é possível substituir a nominalização pela forma verbal "terem desacelerado", resultando na leitura: "os bons resultados se devem a se terem desacelerado os preços". A interpretação nominal ocorre uma vez que "desaceleração" pode estar se referindo ao resultado do ato de reverter a aceleração dos preços. Dessa forma, há duas configurações morfológicas

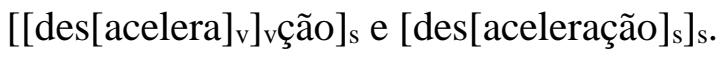

No que se refere ao sentido exercido pelo prefixo "des" neste contexto, entendemos estar diante de uma reversão de estado, pois a estrutura "os bons resultados de fevereiro", aliada à palavra "desaceleração", indica que os preços, anteriormente, estavam passando por um acelerado aumento, porém esse estado foi revertido.

(5) Anteontem, a Federação Internacional de Automobilismo confirmou a desclassificação do alemão [Michael Schumacher], que perdeu seus pontos da corrida, e ainda o suspendeu por mais dois GPs.

A interpretação da nominalização "desclassificação" admite apenas uma possibilidade, que é a verbal, pois a estrutura "confirmou a desclassificação do alemão" poderia ser substituída por "confirmou ter desclassificado o alemão" ou ainda "confirmou desclassificar o alemão", o que aponta o sentido verbal presente na nominalização em questão. Por essa razão, a configuração do item morfológico ocorre da seguinte maneira: $\left[\left[\operatorname{des}[\text { classifica }]_{\mathrm{v}}\right]_{\mathrm{v} c ̧ a ̃ o}\right]_{\mathrm{s}}$.

O sentido do prefixo nesta ocorrência pode apresentar dois sentidos, tanto uma negação quanto uma reversão de estado. A justificativa para a primeira compreensão se dá por meio da informação textual de que o piloto Alemão 
"perdeu seus pontos" resultando em sua "não classificação". Contudo, o elemento textual "e ainda o suspendeu por mais dois GPs" implica a interpretação de que, na verdade, houve uma punição aplicada a Michael Schumacher que resultou na reversão de seu estado anterior que era de "classificado" para "desclassificado". Dessa maneira, é possível afirmar que ambos os sentidos do prefixo pode ser reconhecido neste contexto de uso a depender da leitura do falante.

(6) Segundo o tenente Victor Waldemar Raweri, 50, da PM de Limeira, a polícia invadiu o prédio porque os sem-teto haviam se recusado a cumprir um acordo que teria sido feito na noite de sexta para a desocupação.

Neste contexto, a palavra "desocupação" possui uma interpretação verbal, dado o sentido processual presente nesta nominalização. A estrutura "um acordo que teria sido feito [...] para [...]" denota que seu complemento necessita de propriedades verbais, ou seja, que expressem um ato e não um efeito. Dessa maneira, a nominalização em questão ocorre por meio da adição do prefixo ao verbo ocupar para, depois, adjungir o sufixo ao verbo, resultando na seguinte construção morfológica: $\left[\left[\operatorname{des}[\text { ocupa }]_{v}\right]_{v c ̧ a ̃ o]}\right.$ s.

Em relação ao sentido do prefixo "des" nesta situação de uso, compreendemos como uma reversão de processo, pois a oração "os sem-teto haviam se recusado [...] a cumprir o acordo" indica que o prédio já estava ocupado. Dessa forma, "desocupação" se refere à reversão de ocupar. Por fim, como já explicado anteriormente, o fato de estarmos diante de uma nominalização verbal resulta em uma reversão de processo e não de estado.

(7) Fazer o que muitos de nós fazemos, por exemplo, quando vamos ao Museu Van Gogh, nos detemos extasiados diante das telas do seu período são e passamos algo compungidos pelos trabalhos da última fase em que a desorganização mental do artista se manifesta de maneira tão implacável.

A interpretação da nominalização prefixada em “des-" só pode ser nominal uma vez que, neste contexto, "desorganização" não possui nenhum sentido processual/eventual. Essa afirmação é justificada pelo fato de que o referido 
vocábulo não pode ser substituído por nenhuma forma verbal, mas é possível que ocorra a substituição com a palavra "desequilíbrio" sem que haja desajuste semântico para o enunciado ou, até mesmo, pela estrutura "mente deteriorada", o que realça ainda mais o sentido nominal da nominalização. Dessa maneira, a configuração do item lexical se dá pela adição do prefixo diretamente ao substantivo: [des[organização]s]s.

O sentido do prefixo "des-", nesta ocorrência, é uma reversão de estado uma vez que, analisando o contexto, as estruturas "última fase" e "mente sã" em contraponto com “desorganização mental” revelam que, anteriormente, a cognição do artista Van Gogh estava saudável, mas, posteriormente, ocorreu a mudança desse estado. Além disso, o complemento "de maneira tão implacável” descarta a ideia de processo e reforça o sentido de reversão de estado.

(8) Permitir a proliferação do descrédito do servidor público, dar-lhe atestado de ineficiência, omitir-se diante da campanha de sua difamação, desvalorizá-lo, desmotivá-lo, incutir-lhe o desprestígio, incentivar-lhe a desmotivação e, para culminar, condená-lo a vencimentos aviltantes, significa renunciar à adequada, saudável e necessária boa prestação do serviço público que o país necessita, significa o homicídio doloso da função estatal.

A nominalização "desmotivação" é munida de sentido verbal visto que esse substantivo poderia ser trocado por uma forma do verbo "desmotivar" e constituir o contexto "...lhe incentivando a se desmotivar". Além disso, os complementos anteriores a esta nominalização, a "difamação", a "desvaloziração" e o "desprestígio", são os elementos que atuam como o processo de desmotivação do servidor público, o que resulta na seguinte construção do item lexical: $\left[\left[\operatorname{des}[\text { motiva }]_{v}\right]_{v} c ̧ a ̃ o\right] s$.

O prefixo "des-", nesta ocorrência, pode ser entendido apenas como uma negação. A justificativa para essa afirmação se baseia no uso dos elementos a "desvalorização", a "desmotivação" e o "desprestígio" como resultados de uma "não-motivação" do servidor púbico. Não entendemos essa ocorrência como uma reversão, pois o complemento "a proliferação do descrédito do servidor público" aponta para a compreensão de que esses processos de desmotivação deste 
profissional já existiam, mas apenas foram se intensificando com o passar do tempo. Assim, qualquer sentido de reversão no prefixo é anulado neste contexto.

(9) Como os operadores vinham trabalhando já há alguns dias com a hipótese de desvalorização mais veloz do real em relação ao dólar, a notícia serviu como uma luva para as especulações.

A nominalização "desvalorização" possui interpretação verbal, pois é possível compreender o contexto como “.... hipótese de que o real desvalorizasse mais velozmente em relação ao dólar...". Além disso, o complemento "mais veloz" aponta para a existência de um processo. Dessa maneira, a configuração morfológica do vocábulo é resultante da adjunção do prefixo ao verbo para,

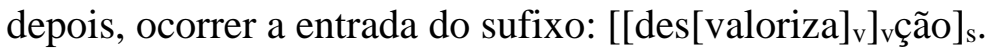

O sentido do prefixo "des", nesta configuração, é uma reversão de processo visto que o contexto estabelece uma comparação entre as moedas "real" e "dólar", de maneira que a primeira passa por um processo de reversão de ser valorizada. É verdade que se poderia argumentar sobre a possibilidade de estarmos diante de uma reversão de estado, porém não acreditamos que seja o caso, pois a estrutura “...vinham trabalhando já há alguns dias...” não deixa dúvidas de que realmente estamos lidando com uma reversão do processo de valorização e não de seu estado.

(10) $\mathrm{O}$ ex-deputado federal Benedito Pinga Fogo de Oliveira, 42, pediu ontem à Justiça Eleitoral de Jandaia do Sul (PR) sua desfiliação do PDT.

A interpretação desta nominalização é verbal devido à possibilidade de trocá-la por uma forma verbal e formular o contexto "o ex-deputado [...] pediu [...] para desfiliar do PDT”, o que revela a natureza processual/eventual da nominalização em questão, de forma que sua configuração é realizada da seguinte

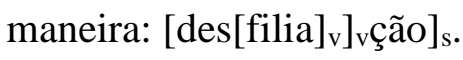

O prefixo "des-" desempenha sentido de reversão de processo, pois o afixo está revertendo a condição de filiado do "ex-deputado federal Benedito". Além 
disso, o complemento "ontem" reforça o entendimento da ocorrência de um processo em detrimento de um estado, pois localiza a ação no tempo.

\section{2.}

\section{Nominalização com formação em sufixo (-mento)}

(1) A greve dos metalúrgicos também tem como uma das causas o descumprimento do acordo da câmara setorial.

Nesta ocorrência, a nominalização prefixada pode ser entendida como uma interpretação nominal ou verbal. Justificamos a possibilidade de uma perspectiva nominal uma vez que "descumprimento" pode estar se referindo ao efeito de “descumprir" que resultou na greve dos metalúrgicos. No entanto, acreditamos que a contraparte verbal desta intepretação, além de possível, seja a mais provável de ser a leitura mais frequente visto que "o descumprimento do acordo" pode ser entendido como o ato/processo de descumprir os acordos. Dessa maneira, a configuração morfológica da palavra pode ocorrer tanto pela adição do prefixo "des" diretamente ao substantivo cumprimento: [des[cumprimento $\left.]_{\mathrm{s}}\right]_{\mathrm{s}}$ como por meio da adição do prefixo ao verbo para a subsequente colocação do sufixo: $\left[\left[\operatorname{des}[\text { cumpri }]_{\mathrm{v}}\right]_{\mathrm{v}} \text { mento }\right]_{\mathrm{s}}$.

No que se refere ao sentido do prefixo, os elementos contextuais apontam para o entendimento de que há evocação de sentido de negação, pois a palavra "greve" é utilizada como resultado ou processo da falta de cumprimento do acordo estabelecido entre os metalúrgicos e a câmara setorial.

(2) No próprio Ministério das Minas e Energia, há sinais fortes de descontentamento, por exemplo, com a atuação do BNDES, gestor do programa de privatização do governo.

A nominalização "descontentamento" possui interpretação nominal uma vez que, neste contexto, ela equivale ao substantivo "insatisfação". Além disso, o 
complemento "sinais fortes" reforça a compreensão de um estado. Dessa forma, o contexto poderia ser entendido como "No próprio Ministério [...], há sinais fortes de insatisfação [...]". A configuração do item lexical se dá por meio da adição do prefixo diretamente ao substantivo deverbal, resultando na estrutura $\left[\operatorname{des}[\text { contentamento }]_{\mathrm{s}}\right]_{\mathrm{s}}$.

Em relação ao sentido do prefixo na palavra "descontentamento", acreditamos que ele seja uma negação (simples), pois, novamente, a estrutura "há sinais fortes de" funciona como elemento intensificador do sentido de negação. Além disso, o prefixo em questão poderia ser trocado pelo advérbio de negação "não".

No entanto, também consideramos válida a possibilidade de que o prefixo também esteja desempenhando o sentido de uma reversão de estado. Ao considerarmos o complemento "com a atuação do BNDES", pode-se inferir que, antes, o estado do Ministério era de contentamento, o que foi revertido por meio da atuação do BNDES. Os dois sentidos podem estar sendo evocados no prefixo, dependendo da leitura, de forma que não há como postular qual das possibilidades é supostamente mais adequada.

(3) O desconhecimento da autoria do crime não impede a instauração do inquérito policial: ele tem precisamente a finalidade de apurar a materialidade do fato e a autoria do crime.

Neste contexto da palavra "desconhecimento", estamos diante de duas possibilidades de interpretação. A interpretação verbal é justificada por meio da substituição de "desconhecimento" pela sua forma verbal no infinitivo. Assim, teríamos, como contexto, "o desconhecer a autoria do crime não impede...". A palavra nominalizada assume a interpretação de "o ato de desconhecer".

A interpretação nominal também ocorre, pois a estrutura "o desconhecimento" pode ser entendida como o resultado/efeito desconhecer. Assim, o contexto poderia ser compreendido como "A insciência da autoria do crime não impede...”. Por este motivo, a configuração de "desconhecimento" tanto pode ser realizada a partir da adjunção do prefixo ao verbo, como em 
$\left[\left[\operatorname{des}[\text { conhece }]_{\mathrm{v}}\right]_{\mathrm{v}}(\mathrm{i}) \text { mento }\right]_{\mathrm{s}}$, como pela colocação do prefixo diretamente ao substantivo conhecimento: [des[conhecimento $\left.]_{\mathrm{s}}\right]_{\mathrm{s}}$.

Em relação ao sentido do prefixo, entendemos ser o caso de uma negação, pois o prefixo pode ser substituído pelo advérbio de negação "não". Dessa maneira, neste contexto de uso, "o desconhecimento" equivale a "o nãoconhecimento".

(4) Cercada por um desconhecimento geral no Brasil e envolvida por um modismo em outros países europeus, essa instituição surgiu no processo constituinte como objeto de polêmica.

Em se tratando do vocábulo "desconhecimento", neste contexto, ocorre a interpretação nominal. A justificativa para esta compreensão se dá pelo fato de que esta nominalização pode ser substituída pela palavra "a ignorância". Assim, teríamos o contexto "cercada por uma ignorância geral no Brasil...”. Além disso, não há a possibilidade de utilização de nenhuma forma verbal nesta ocorrência, o que corrobora para o entendimento de que não esteja ocorrendo uma interpretação verbal. Por fim, o complemento "cercada por um" reforça uma leitura nominal da nominalização uma vez que essa estrutura pressupõe um estado e não uma ação.

No tocante ao sentido do prefixo "des-" na referida palavra, acreditamos que ele seja uma negação uma vez que o afixo poderia ser substituído pelo advérbio de negação simples. Além disso, não se poderia pensar em reversão, pois não há nenhuma informação contextual que se refira ao estado anterior de conhecimento no Brasil sobre esta instituição.

(5) Inúmeras tentativas de cessar-fogo fracassam, assim como acordos de desarmamento gradual das forças em conflito.

No que diz respeito à interpretação da nominalização, ela apenas apresenta sentido verbal. Entendemos, a partir da leitura do contexto, que se pode inferir um processo em que as forças em conflito deixariam de adquirir novos equipamentos bélicos. Além disso, o adjetivo "gradual” funciona como mais uma evidência para a ocorrência de um processo, o que nos leva a entender que a interpretação 
nominal não seria uma alternativa possível neste contexto já que o referido recurso textual indica um processo/ato. Dessa forma, a interpretação da nominalização, neste contexto, é a verbal, de maneira que o prefixo "des" se coloca ao lado do verbo para depois haver a nominalização, como em $\left[\left[\operatorname{des}[\operatorname{arma}]_{\mathrm{v}}\right]_{\mathrm{v}} \text { mento }\right]_{\mathrm{s}}$.

(6) O vibrião do cólera, entretanto, pode sobreviver por longo tempo em alimentos congelados contaminados e neste caso apresentam alto risco se ingeridos crus, após o descongelamento.

A nominalização "descongelamento", a partir da análise do contexto de uso, assume apenas o sentido verbal, embora haja duas possibilidades de leitura da frase. A referência a "alimentos congelados contaminados" implica uma ideia de estado do alimento e não a um processo. Assim, "descongelamento" pode ser entendido como a reversão do estado de congelado. Além disso, também é possível compreender descongelamento como o processo/ato de descongelar, principalmente se for levado em consideração a estrutura "após o" que pode pressupor tanto o processo de descongelar ou o estado que se resultou subsequentemente a esta ação. Dessa maneira, não há elementos contextuais suficientes que apontem qual leitura seria, supostamente, a mais adequada. De qualquer forma, a nominalização, nestas ocorrências, apenas ocorre a partir da adjunção do prefixo ao verbo para, depois, haver a entrada do sufixo nominalizador, formando a seguinte configuração: [[des[congela $\left.]_{\mathrm{v}}\right]_{\mathrm{v}}$ mento $]_{\mathrm{s}}$.

(7) A queda da arrecadação, que começou mesmo em dezembro, está assustando os técnicos da Secretaria da Receita Federal por uma razão muito simples: os dados mostram um inequívoco processo de desaquecimento da economia, a despeito dos outros indicadores de vendas, que estariam apontando em direção contrária.

A interpretação da nominalização nesta ocorrência seria verbal visto que elementos textuais sustentam este entendimento, como o uso da estrutura "processo de". Em adição, a oração "está assustando os técnicos da Secretaria da 
Receita Federal" aponta para a compreensão de que o "desaquecimento" ocorre de forma gradual e processual, o que enfatiza o caráter eventual da nominalização e elimina a possibilidade de uma interpretação nominal. A configuração do vocábulo "desaquecimento" seria $\left[\left[\operatorname{des}[\text { aqueci }]_{\mathrm{v}}\right]_{\mathrm{v}} \text { mento }\right]_{\mathrm{s}}$. Em relação ao sentido desempenhado pelo prefixo, entendemos se tratar de uma reversão de processo devido à interpretação verbal da nominalização.

(8) Do exterior, Maluf mandou um basta aos desentendimento domésticos do PPR, em torno do apoio do partido à candidatura de Luiz Antônio de Medeiros (PP) ao governo paulista.

A nominalização em questão é de interpretação nominal, pois ela não possui sentido verbal. Além disso, o substantivo "briga" poderia substituir a referida nominalização sem que houvesse desajuste à compreensão do enunciado e constituir o seguinte contexto "...Maluf mandou um basta às brigas domésticas...”. Assim, a configuração morfológica deste item lexical ocorre a partir da adição do prefixo diretamente ao substantivo: [des[entendimento]s $]_{s}$. O sentido do prefixo "des", nesse contexto, é de negação (se usarmos a inferência, seria uma negação por falta). Justificamos esse entendimento uma vez que o afixo equivaleria ao advérbio de negação "não".

(9) Demonstrando um certo desentrosamento e um excesso de preciosismo na finalização, os palmeirenses acabaram afunilando as jogadas para o meio.

Entendemos que essa nominalização possui intepretação nominal visto que não é possível utilizar uma forma verbal para substituir a nominalização sem haver alteração de sentido no contexto. Assim, "desentrosamento" é entendido como o efeito e não a ação de desentrosar, de maneira que a nominalização, neste contexto, se equivale à palavra "desajuste". A construção da palavra, dessa forma, seria: $\left[\text { des }[\text { entrosamento }]_{s}\right]_{s}$.

Em relação ao sentido do prefixo, compreendemos que se trata de uma negação, pois o complemento “...acabaram afunilando as jogadas para o meio" indica que essa deficiência em progredir as jogadas ocorreu em virtude de um(a) 
não/falta de entrosamento dos palmeirenses. Assim, descarta-se a possibilidade de uma reversão, pois não há elementos contextuais que indiquem que antes havia entrosamento entre os jogadores.

(10) A preocupação foi evitar o descasamento entre a correção financeira do custeio 94/95 com os financiamentos já concedidos ( sic)

A interpretação dessa nominalização é nominal uma vez que "descasamento" pode ser entendido como "discrepância", o que resulta no contexto “A preocupação foi evitar a discrepância entre...". Adicionalmente, o complemento "entre a correção financeira [...] com os financiamentos já concedidos" apontam para o entendimento de que há um estado de equilíbrio entre as duas ações, o que reforça a interpretação nominal. Em relação à configuração da palavra, ela seria $\left[\operatorname{des}[\text { casamento }]_{\mathrm{s}}\right]_{\mathrm{s}}$.

Nesta situação, compreendemos que o sentido do prefixo como uma reversão de estado. Justificamos esse entendimento, pois a estrutura "a preocupação foi evitar" indica que, nesta situação, o valor da correção financeira do custeio e dos financiamentos estavam afins; logo, o objetivo era impedir que houvesse a reversão desse estado.

\section{3.}

Nominalização com sufixos minoritários (-agem, -ança e ência)

(1) De manhã, depois de uma rápida refeição e desmontagem da barraca, eles ligaram o transmissor ELT (Emergency Locator Transmitter) durante a passagem do satélite SARSAT / COSPAS.

A interpretação da nominalização é verbal uma vez que existe a possibilidade de substituir a nominalização por uma forma do verbo que o originou, como em: “[...] depois de uma rápida refeição e de desmontar a barraca [...]", o que por si só evidencia a contraparte verbal da nominalização analisada. A 
configuração do item lexical ocorre a partir da adição do prefixo ao verbo para depois haver a entrada do sufixo: $\left[\left[\operatorname{des}[\text { monta }]_{\mathrm{v}}\right]_{\mathrm{v}} \mathrm{gem}\right]_{\mathrm{s}}$.

Em relação ao sentido do prefixo, compreendemos estar diante uma reversão de processo, pois o complemento "depois de uma rápida refeição" indica que, após este evento, ocorreu o processo de desmontar a barraca.

(2) Se, por exemplo, num sábado ou domingo à tarde, nos dedicarmos à prática do zapping, não corremos o risco de encontrar, em todos os canais, a mesma partida esportiva, enfocada pelo mesmo ângulo de câmera e acompanhada do mesmo estilo de comentário? Assim, o prazer perverso de uma desregulagem da máquina produtiva da televisão pode resultar, pura e simplesmente, na mesma apatia indiferenciada da recepção passiva, ou na frustração diante do determinismo estrutural do dispositivo simbólico.

Neste contexto, a nominalização possui interpretação verbal uma vez que é possível utilizar o verbo base no infinitivo no lugar da palavra nominalizada e estabelecer a seguinte leitura: “Assim, o prazer perverso de desregular a máquina produtiva da televisão pode resultar...”. Por este motivo, o vocábulo é constituído por meio da entrada do prefixo diretamente ao verbo e, por fim, ocorre a nominalização: [[des[regula $\left.]_{v}\right]_{v}$ gem $]_{s}$.

O prefixo "des-", nesta ocorrência, possui sentido de negação visto que o afixo pode ser trocado pelo advérbio de negação "não" sem prejudicar profundamente o contexto em que o vocábulo analisado se encontra. Dessa maneira, "não regulagem da máquina produtiva da televisão" é que resulta na indiferença e frustação diante dos conteúdos consumidos.

(3) A desplugagem ${ }^{8}$ do cabo abre a melodia, o ritmo e a harmonia para situações inéditas. Isso se verifica especialmente na harmonização.

\footnotetext{
${ }^{8}$ É importante explicar que se trata de uma palavra não dicionarizada, mas de uso difundido no uso cotidiano, sobretudo em contextos de informática e mecânica. Quanto a sua origem, ela surgiu a partir da importação da palavra "plug" da Língua Inglesa que resultou na formação do verbo "plugar" no Português e suas palavras derivadas. Exemplos de utilização deste vocábulo em outros contextos reais de uso podem ser apreciados nos links a seguir:
} 
A nominalização é verbal, pois o contexto pode ser interpretado como: “desplugar o cabo abre a melodia...".. Em virtude disso, o substantivo "desplugagem" é constituído por meio da adjunção do prefixo "des" ao verbo "plugar" para, só depois, haver a colocação do prefixo "agem": $\left[\left[\operatorname{des}[\text { pluga }]_{\mathrm{v}}\right]_{\mathrm{v}} \text { agem }\right]_{\mathrm{s}}$. Adicionalmente, o prefixo possui sentido de reversão de processo.

(4) Todo o seu esforço como historiador pode ser caracterizado como uma promoção constante da deslembrança das coisas passadas.

A nominalização apresenta interpretação nominal. Justificamos esse entendimento visto que a substituição da palavra ocorre com a forma verbal nominalizada, o que é explicitado pelo uso do artigo na paráfrase do contexto como em: "todo o seu esforço [...] pode ser caracterizado como uma promoção constante do deslembrar de coisas passadas". Assim, seria uma estrutura com a configuração $\left[\operatorname{des}[\text { lembrança }]_{s}\right]_{s}$.

Em relação ao sentido do prefixo, entendemos estar diante de uma reversão de processo uma vez que o complemento "historiador" indica que seu "constante esforço" estaria voltado para reverter o natural processo de esquecimento para com "as coisas passadas". Por isso, seria inadequado pensar que o prefixo estaria desempenhando uma negação, pois a função de um historiador, a princípio, não seria negar os acontecimentos passados, mas sim evitar que eles sejam esquecidos.

(5) Um advogado próximo aos Magalhães Pinto disse que os problemas do banco começaram com a desconfiança do mercado após o caso Econômico.

A interpretação da nominalização é verbal, pois há a possibilidade de substituí-la por uma forma de seu verbo base sem que haja muito prejuízo ao

http://www.rtsrio.com.br/index.php?pag=produtos-detalhe\&prod_id=219 Acesso no dia $20 \mathrm{de}$ outubro de 2019 /https://www.dicionarioinformal.com.br/desplugar/ Acesso no dia 8 de outubro de 2019 
contexto analisado, como em "um dos advogados disse [...] que os problemas do banco começaram ao desconfiar do mercado [...]". Dessa forma, a palavra é constituída da seguinte forma: $\left[\left[\text { des }[\text { confia }]_{\mathrm{v}}\right]_{\mathrm{v}} \mathrm{ança}\right]_{\mathrm{s}}$.

O sentido do prefixo é uma reverão de estado, pois os "problemas do banco" surgem a partir da reversão da confiança na solidez das reservas bancárias. Ou seja, seria a reversão do estado de confiança. No entanto, é possível afirmar que também há a possibilidade de entender o prefixo como uma negação, pois "os problemas bancários" também pode resultar a partir da "não e/ou falta de confiança".

O sentido do prefixo é uma negação, pois o afixo “des-" está apenas negando a palavra base a que se adjungiu. Assim, o contexto pode ser entendido como "[...] os problemas do banco começaram com a falta de confiança do mercado $[\ldots] "$.

(6) O governador considerou ainda "uma maldade trazer desconfiança contra uma instituição como a Polícia do Rio, que está em processo de recuperação”.

Neste contexto, entendemos que a interpretação da nominalização é nominal uma vez que o complemento "uma maldade" seria resultante do estado de desconfiar da polícia do Rio. Dessa maneira, a palavra é estruturada como: $\left[\operatorname{des}[\text { confiança }]_{\mathrm{s}}\right]_{\mathrm{s}}$.

O sentido do prefixo, nesta ocorrência, é uma reversão de estado, pois o complemento "está em processo de recuperação" aponta para o entendimento de que a confiança anteriormente fora perdida e agora está em um curso de reestabelecimento gradual. Assim, "trazer desconfiança" seria reverter o estado confiável para não confiável novamente.

(7) A página lista 24 ações possíveis contra a lei americana (apelidada de CDA, Communications Decency Act), e logo de cara lembra: a desobediência civil é ilegal e pode causar prisão e processos e aconselha a pensar com cuidado antes de agir. 
Em se tratando da interpretação da nominalização, acreditamos que seja verbal uma vez que o contexto poderia ser entendido como "desobedecer é ilegal", o que aponta para a existência de uma ação na palavra nominalizada. Além disso, o complemento "é ilegal" intensifica a intepretação de que realmente seja o caso de uma ação visto que ela ainda "pode causar prisão e processos". Assim, a configuração do item lexical seria $\left[\left[\operatorname{des}[\text { obedece }]_{v}\right]_{v} \text { ência }\right]_{s}$. Em relação ao sentido do prefixo, seria uma negação visto que a palavra "desobediência" equivale a "não obediência".

(8) Pode-se estabelecer uma íntima relação entre a violência praticada contra os povos indígenas com a política adotada pelo governo quanto ao programa administrativo de demarcação das terras, à desassistência e à omissão na proteção desses povos.

A nominalização "desassistência" possui interpretação nominal uma vez que ela não denota ação. Em adição, ela pode ser substituída pelo substantivo "desamparo". O contexto, então, seria "Pode-se estabelecer uma íntima relação entre a violência praticada contra os povos indígenas [...] com o desamparo e à omissão na proteção desses povos". Dessa maneira, o prefixo "des-" se adjunge diretamente ao substantivo: $\left.[\text { des[assistência }]_{\mathrm{s}}\right]_{\mathrm{s}}$.

O prefixo possui sentido de negação (por inferência, negação por falta) visto que o afixo equivaleria ao advérbio de negação simples "não". Contudo, é possível entender que também estamos diante de uma oposição enfática, pois o complemento "a política adotada pelo governo quanto ao programa administrativo de demarcação das terras" e "a omissão na proteção desses povos" seriam não apenas uma "falta de assistência", mas sim uma "antiassistência" visto que ela resulta na violência praticada contra o povo indígena.

(9) Assim, quem ficou na marca do pênalti é César Sampaio, por quem o treinador brasileiro nutre certa “despreferência”, para usar o termo lexicamente mais incorreto, porém menos infiel. 
A intepretação da nominalização é nominal, o que se pode confirmar pela impossibilidade da substituição por uma forma verbal. Adicionalmente, "despreferência", neste contexto, equivaleria a algo próximo dos substantivos "impaciência" ou "desfavoritismo". Além disso, o complemento "por quem o treinador brasileiro nutre certa" indica que a nominalização se refere a um tipo de sentimento e não uma ação. A palavra é constituída pela adição do prefixo diretamente ao substantivo: [des[preferência $\left.]_{s}\right]_{s}$. Em relação ao sentido, acreditamos se tratar de uma negação dada a possibilidade de compreender a palavra como uma "não preferência" e/ou "falta de preferência".

(10) A Companhia das Letras, à qual está vinculada a professora-editora, não colaborou em nada com a apresentação brasileira, recusou-se a convidar seus autores para Frankfurt (quem apareceu por lá ou foi convidado pelo governo ou foi conta própria), como também o seu editor Luis Schwarcz deu repetidas declarações sobre a "desimportância” do evento.

A nominalização "desimportância" possui interpretação nominal. Justificamos essa proposição visto que o complemento "deu repetidas declarações sobre" aponta para o entendimento de que "desimportância" se refere ao estado de irrelevância do "evento". Por isso, a construção da palavra ocorre a partir da adjunção do prefixo ao substantivo: [des[importância $\left.]_{\mathrm{s}}\right]_{\mathrm{s}}$. Em se tratando do sentido do prefixo, pensamos ser o caso de uma negação uma vez que o contexto pode ser entendido como "[...] Luis Schwarcz deu repetidas declarações sobre a não e/ou falta de importância do evento".

\section{4 .}

\section{Substantivos deverbais}

(1) Os infratores da lei que tornou obrigatório o uso do cinto de segurança e os motoristas que tiveram os carros flagrados sobre as calçadas começam a receber, a 
partir da próxima semana, as multas por desrespeito ao código de posturas do município.

A acepção do prefixo é uma negação, o que pode ser comprovado a partir da aplicação de multas como consequência do "não respeito" ao "código de posturas do município" por meio da falta de utilização do cinto de segurança ou estacionar sobre a calçada". Dessa forma, excluem-se as possibilidades de reversão.

(2) Em nota oficial, o BC afirmou que a instituição vinha apresentando desequilíbrio financeiro e depreciação patrimonial, decorrente de elevado índice de inadimplência em operações de crédito.

O sentido do afixo "des-", nesta ocorrência, é uma reversão de estado. Justificamos essa interpretação, pois o complemento "a instituição vinha apresentando" aponta para a ocorrência da reversão gradual do estado de equilibrado até tornar-se desequilibrado, como consequência da inadimplência.

(3) Com toda nossa falta de fé, com todo o nosso profundo desinteresse pelo fenômeno religioso, somos um pouco como Schopenhauer, que se julgava emancipado da fé cristã, mas que, na verdade, adotava um cristianismo invertido.

Neste contexto, a palavra prefixada possui sentido de oposição. Entendemos que esta afirmação é discutível, pois poder-se-ia considerá-la como um caso de negação. Contudo, a estrutura "com toda a nossa falta de fé" e o complemento "com todo o nosso profundo" atuam como intensificadores que apontam para uma leitura de que "desinteresse" não seja apenas uma "falta de interesse", mas uma forma de "anti-interesse", ainda mais ao considerarmos a estrutura “[...] somos um pouco como Schopenhauer [...] que adotava um cristianismo invertido", o que torna ainda mais claro que não se trata de um "nãointeresse" para com o cristianismo e sim de uma oposição a ponto de invertê-lo. 
(4) Inflação de demanda, citada por Lula, ocorre quando há um descontrole dos preços em razão de um crescimento acelerado do consumo.

A acepção do prefixo é uma reversão de estado, pois o "crescimento acelerado do consumo" tem, como consequência, a reversão do estado de controlado dos preços. Em adição, o complemento temporal "quando" fortifica o apontamento para o sentido reversativo uma vez que entende-se que o “descontrole dos preços” é uma situação dinâmica e está condicionada a outros fatores que atuam na reversão de sua estabilidade.

(5) Um curso técnico de telemarketing, noções mínimas de informática e de vendas podem contar favoravelmente no desempate para conquistar uma vaga.

O sentido do prefixo, nesta ocorrência, é uma reversão de estado, pois os complementos "curso técnico de telemarketing, noções mínimas de informática e de venda" atuam como elementos que revertem o estado de empatado entre dois ou mais hipotéticos candidatos.

(6) O meu desencanto é maior quando sinto que não há, por parte das autoridades deste país, o mínimo interesse de investir em promoção de saúde e prevenção de doenças.

A acepção de "des-" é reversão de estado. Entendemos desta forma, pois o contexto aponta para a compreensão de que a falta de interesse no investimento da promoção de saúde e prevenção de doenças, por parte das autoridades responsáveis do país, é que revertem o estado de encantamento do falante.

(7) O desajuste financeiro provocado pelo excesso de gastos obrigou a prefeitura a recorrer aos chamados empréstimos bancários por antecipação de receita, pagando juros reais de $27 \%$ ao ano mais a TR.

Estabelecemos o sentido do prefixo como uma reversão de estado neste contexto visto que o complemento "excesso de gastos" resultou na necessidade de 
recorrer a empréstimos bancários que tiveram, como consequência, a reversão do estado de ajustado da parte financeira da prefeitura.

(8) Depois de tantos anos de desestímulo ao trabalho do professor, faltam bons profissionais no mercado.

O sentido do prefixo, nesta ocorrência, é uma negação, pois é possível entender o contexto como "depois de tantos anos de falta/não estímulo ao trabalho do professor [...]”, o que resultou na escassez de profissionais capacitados.

(9) O presidente da Cosipa durante o desgoverno Collor, Antônio Dal Fabro, entregou a siderúrgica à beira do colapso, mas seu patrimônio começou a crescer durante o período em que ocupou a presidência.

A acepção de "des-" é uma oposição uma vez que "desgoverno" não se trata de um governo que não acontece, o que é terminantemente descartado pelo complemento "durante", que indica a ocorrência do ato de governar. Também não poderíamos pensar em "desgoverno" como uma reversão do estado de governado, mas sim como um "antigoverno" e/ou "governo ruim".

(10) O Brasil todo calçar chuteiras em época de Copa do Mundo é visto por uns alguns, aqui e lá fora, como manifestação de atraso, de desapego à ética do trabalho.

O sentido do prefixo é uma reversão de estado visto que o complemento "O Brasil todo caçar chuteiras em época de Copa do Mundo" indica que seja um hábito temporalmente localizado. Portanto, neste período, haveria uma reversão do estado de apego à ética do trabalho, conforme é possível entender a partir do contexto. 


\section{5.}

\section{Resultados das análises}

Conforme visto anteriormente, este corpus é formado por 125 substantivos de ação transparente e os resultados alcançados reafirmam as acepções da negação e da reversão de estado como sendo as mais frequentes uma vez que ambas ocorreram em 54 das 125 palavras deste corpus, o que representa $43,2 \%$ de todos os usos.

A reversão de processo e a oposição, embora tenhamos registrado suas ocorrências, possuem um baixo número de recorrência, tendo registro de 17 e de 16 ocorrências em 125 palavras, respectivamente. Assim, a reversão de processo representa $13,6 \%$ de todos os usos ao passo que a oposição constitui $12,8 \%$ da utilização total.

Nossos resultados estão resumidos no quadro abaixo:

Quadro 1 - Frequência das acepções do prefixo "des-"

\begin{tabular}{|c|c|c|}
\hline ACEPÇÕES & OCORRÊNCIA & PORCENTAGEM \\
\hline Negação & 54 em 125 palavras & $43,2 \%$ \\
\hline Reversão de estado & 54 em 125 palavras & $43,2 \%$ \\
\hline Reversão de processo & 17 em 125 palavras & $13,6 \%$ \\
\hline Oposição (enfática) & 16 em 125 palavras & $12,8 \%$ \\
\hline
\end{tabular}

É válido destacar que, embora não seja expressivamente majoritária, a acepção de oposição enfática claramente se configura como um mecanismo frequente na utilização do falante de português brasileiro contemporâneo. Naturalmente, o fato de seu uso ser estilístico consequentemente faz com que este seja mais restrito, pois sua utilização se dá em situações em que se pretende estabelecer determinado uso expressivo. 
5.

\section{Considerações finais}

Neste trabalho, nós pudemos acompanhar as principais tendências de estudos sobre o prefixo “des" existentes em Língua Portuguesa a partir de diferentes abordagens, perpassando desde a tradição gramatical às principais perspectivas do gerativismo. Adiante, estabelecemos contato com as propostas essenciais da Linguística Cognitiva que podem ser aplicadas à análise e investigação do sentido do prefixo e da formação de palavras.

A pesquisa sobre o prefixo "des-" no PB é uma temática recorrente, o que resultou na multiplicidade de trabalhos relevantes já existente sobre o assunto. Contudo, uma das discordâncias mais frequentes em relação a este afixo é a gama de sentidos que ele possui. Há, até mesmo, discordância se o "des-” deveria ser ou não considerado uma variante do prefixo "dis", ou quais tipos de negações e reversões ele viabiliza à palavra que se adjunge.

É importante reconhecer, ainda, a variedade de propostas apresentadas pelas diferentes abordagens linguísticas. Entre elas, destaca-se a proposição da perspectiva gerativa ao estabelecer a hipótese de prefixos homônimos. Mais especificamente, um possui sentido negativo e se adjunge à adjetivos e o outro, cujo sentido é reversativo, se acopla a verbos. Sob esta hipótese, o sentido do afixo só passa a ser reconhecido depois de um processo sintático que primeiro determina a base para, posteriormente, acessar o significado. Essa proposta, em consequência, terminaria com as ambiguidades existentes nas construções dos itens lexicais. Entretanto, em relação a esta contribuição, foram apontadas inconsistências, tais como a ocorrência de verbos na Língua Portuguesa prefixados em "des-", cujo sentido é negativo em vez de reversativo, o que põe em xeque a postulação de prefixos homônimos pelo menos nesses casos.

Em se tratando de nossa pesquisa, partimos da concepção de que o prefixo possui natureza polissêmica e, além disso, apenas a partir do acesso ao contexto de uso é que de fato será possível compreender claramente o sentido do afixo. Por este motivo, decidimos utilizar o corpus NILC uma vez que ele é composto por ocorrências da língua em uso. 
O pressuposto de analisar as acepções do prefixo "des" em uma perspectiva baseada no uso mostrou-se adequado uma vez que, em nossa pesquisa, foi constatado que, dependendo do enunciado em que esteja inserida, uma mesma palavra prefixada pode apresentar acepções diferentes, conforme os exemplos (1) e (2) a seguir:

(1) A desvalorização dos professores é uma das causas da baixa qualidade de ensino, aponta especialista. O Globo - 02 de Fevereiro de 2009. ${ }^{9}$

(2) Carros esportivos têm desvalorização média de $8 \%$ em um ano. Revista Valor Investe -16 de novembro de $2019^{10}$

Como é possível analisar, na primeira ocorrência o prefixo "des" equivale ao advérbio de negação "não" ou à estrutura "a falta". Assim, "a falta de valorização dos professores é uma das causas...", o que implica afirmar que o sentido desempenhando pelo afixo neste enunciado é negativo. Contudo, é de suma importância destacar que, neste mesmo enunciado, o vocábulo "desvalorização" também pode ser entendido como a reversão do estado de valorizado do professor e isso se daria com base no conhecimento enciclopédico do falante uma vez que a atuação do profissional da educação tem sido cada vez mais desvalorizada e, até mesmo, passado por ataques que resultam ainda mais em uma perda de valor da categoria.

Ao analisarmos o segundo contexto, a palavra "desvalorização" não é simplesmente "não valorizado", mas sim uma reversão do estado de valorizado dos carros esportivos e o elemento (con)textual "média de $8 \%$ em um ano" intensifica de tal forma a acepção de reversão de valorizado que apenas este sentido poderia ser ativado nesta situação. Destacamos ainda que, neste contexto, talvez fosse mais preciso estabelecer que se trata de uma mudança de estado. Dessa maneira, é evidenciado que não é suficiente apenas afirmar que

\footnotetext{
${ }^{9} \mathrm{~A}$ matéria pode ser acessada neste link https://oglobo.globo.com/sociedade/educacao/desvalorizacao-dos-professores-uma-das-causasda-baixa-qualidade-do-ensino-aponta-especialista-3129947 Acesso no dia 20 de janeiro de 2020

${ }^{10} \mathrm{https} / /$ valorinveste.globo.com/objetivo/gastar-bem/noticia/2019/11/16/carros-esportivostem-desvalorizacao-media-de-8percent-em-um-ano.ghtml Acesso no dia 20 de janeiro de 2020
} 
“desvalorização" é uma reversão ou uma negação, pois apenas por meio do contexto e do uso é que a acepção pode ser plenamente compreendida.

Em termos quantitativos, vimos neste trabalho que a reversão de estado e a negação foram as acepções mais frequentes nas construções dos itens lexicais. Em relação à reversão de processo, essa acepção figura como o terceiro sentido mais frequente neste trabalho. Acreditamos que esta baixa ocorrência em termos de uso se deva a maior necessidade de elementos contextuais para que o sentido seja evocado, o que pode ser, de alguma forma, mais custoso para o falante.

Em adição, o sentido de oposição é menos frequente o que é, de certa forma, previsível uma vez que ele proporciona ao vocábulo uma carga estilística e/ou expressiva o que, por si só, já restringe suas motivações de uso para circunstâncias mais específicas.

Em relação às contribuições sociais advindas desta pesquisa, consideramos que este trabalho pode ser utilizado de forma proveitosa para a exploração das possibilidades de sentidos ativados nas construções lexicais, principalmente em se tratando do ensino de português, em especial para estrangeiros, uma vez que os dicionários tradicionais não costumam fazer referência ao contexto de uso como um elemento determinante para a acepção que será desempenhada pelo prefixo.

Por fim, esperamos que esta dissertação possa colaborar para a compreensão das acepções do prefixo "des” em uma abordagem da língua em uso. É válido destacar que, pelo fato de nosso trabalho ter tratado apenas dos substantivos de ação, cujo foco estava na investigação da acepção do prefixo em seu contexto de uso, ainda é necessário aprofundamento para outras questões que, devido ao curto tempo e a extensão deste trabalho, não foram abordadas, tal como a importância do sentido do verbo/nome base para a evocação do sentido do prefixo "des-". Caberia analisar de que maneira e até que ponto a acepção seria influenciada pela configuração morfológica; além disso, como o conhecimento enciclopédico do falante auxiliaria na ativação do sentido do "des-". São questões que ainda permanecem em aberto e que certamente se constituem como um interessante objeto de pesquisa para trabalhos futuros. 


\section{6.}

\section{Referências Bibliográficas}

ANDERSON, S.R. Where's Morphology. Linguistic Inquiry, v. 13, n. 4, p. 571-612, 1982.

ANDRADE, F. G. C. Polissemia e produtividade nas construções lexicais: um estudo do prefixo re- no português contemporâneo. (Dissertação de Mestrado). Rio de Janeiro. Pontifícia Universidade Católica do Rio de Janeiro - PUC-Rio, Departamento de Letras, 2006.

BASÍLIO, M. M. P.. Estruturas Lexicais do Português: uma abordagem gerativa. Petrópolis: Vozes, 1980.

. O princípio da analogia na constituição do léxico: regras são clichês lexicais. Veredas (UFRJ), Juiz de Fora, v. 1, p. 9-21, 1997.

. Formação e classe de palavras no português do Brasil. São Paulo: Contexto, 2004.

. Teoria lexical. 8 ed., São Paulo: Ática, 2007.

. Abordagem gerativa e abordagem cognitiva na formação de palavras: considerações preliminares. Revista Linguística, Rio de Janeiro, v. 6, 2010.

BEBER, S. T. Linguística de corpus. Barueri: Editora Manole, 2004.

BECHARA, E. Moderna Gramática Portuguesa. $37^{a}$ ed. Rio de Janeiro: Lucerna, 2009.

BYBEE, J. Morphology as Lexical Organization. In: M. Hammond e M. Noonan

(eds)

Theoretical Morphology. New York: Academic Press, 1988.

University Press, 2010.

Language, Usage and Cognition. Cambridge: Cambridge

CÂMARA JR, J. M. Estrutura da língua portuguesa. 38 ed. Petrópolis: Vozes, 2006.

. Dicionário de Linguística. 26ª Ed. Petrópolis: Vozes, 2011.

CROFT, W. CRUSE, A. Cognitive Linguistics. Cambridge: Cambridge University Press, 2004. 
CUNHA, C. \& CINTRA, L. Cintra. Gramática do português contemporâneo. 6ª ed. Rio de Janeiro: Lexikon, 2013.

DE BONA, C. 2014. Os prefixos de negação des- e in- no PB: Considerações morfossemânticas. Dissertação (Mestrado em Letras), Instituto de Letras, UFRGS, Porto Alegre.

; RIBEIRO, P. N. Sobre a produtividade e a semântica do prefixo des- no português brasileiro atual. DELTA. DOCUMENTAÇÃO DE ESTUDOS EM LINGUÍSTICA TEÓRICA E APLICADA (PUCSP. IMPRESSO), v. 34, p. 611-634, 2018.

DI SCIULLO, A.; WILLIAMS, E. On the definition of word, Massachusetts: MIT Press, 1987.

DOLINKS, J. T. Aspectos morfossintáticos, semânticos e estilísticos dos prefixos negativos na formação de palavras em português. Curitiba: UFPR, 1993. Dissertação de Mestrado.

FERNANDES, F. Dicionário de verbos e regimes. 4 ed. Porto Alegre: Editora Globo, 1972 [1940].

FERRARI, L. Introdução à linguística cognitiva. São Paulo: Contexto, 2018.

FILLMORE, C. Frame semantics. In LINGUISTIC SOCIETY OF KOREA (ed.) Linguistics in the modern calm. Seoul, Hanshin Pubishing, 1982, p. 111-137.

FODOR, J.; KATZ, J. The structure of language; readings in the philosophy of language. Englewood Cliffs: Prentice-Hall, 1964.

GONÇALVES, C. A. V. Iniciação aos estudos morfológicos: flexão e derivação em português.1 ed. São Paulo, Contexto, 2011.

HOUAISS. Dicionário eletrônico Houaiss da língua portuguesa. Rio de Janeiro: Objetiva, 2001.

JOHNSON, M. The body in the mind: the bodily basis of meaning, imagination, and reason. Chicago: University of Chicago Press, 1990.

HALLIDAY, M. A. K. An introduction to functional grammar. London: Hodder Headline Group, 2004.

HULL C. L. Quantitative aspects of the evolution of concepts. Psychological Monographs, v. 38, n.123, p.1-86, 1920 
LAKOFF, G.; JOHNSON, M. Metáforas da vida cotidiana. Campinas: Mercado de Letras/ Educ, 2002 [1980].

LANGACKER, R. Foundations of cognitive grammar. Theoretical prerequisites.Stanford: Stanford University Press, 1987.

Cognitive grammar. Oxford: Oxford University Press, 2008.

Concept, image and symbol: the cognitive basis of grammar. New York: Mouton de Gruyter, 1991.

de Gruyter, 2009.

Investigations in cognitive grammar. New York: Mouton

LEVELT, W. J. Speaking: from intention to articulation. Massachusetts: MIT Press, 1993.

LIEBER, R. Morphology and Lexical Semantics. Cambridge: Cambridge University Press, 2004.

LIPKA, L. An outline of English lexicology (Lexical Structure, Word Semantics and Word-Formation). Tübingen : Max Niemeyer Verlag Tübingen, 1992.

LOURENÇO, E. S. O advento da Morfologia Distribuída. ReVEL, vol. 8, n. 14, 2010.

MEDEIROS, A. B. Para uma abordagem sintático-semântica do prefixo des-. Revista da ABRALIN, vol.9, n.2: 95-121, 2010.

MONTEIRO, J. L. Morfologia portuguesa. $4^{\underline{a}}$ ed. Campinas: Pontes, 2002.

NUNES et al. "a Construção de um léxico para o português do Brasil: Lições aprendidas e perspectivas". In: Anais do II Encontro para o processamento do português escrito e falado (Curitiba, PR, 21-22 de outubro de 1996a), Curitiba: CEFET-PR, p. 61-70.

. "Desenvolvimento de um sistema de revisão gramatical automática para o português do Brasil". In: Anais do II Encontro para o processamento do português escrito e falado (Curitiba, PR, 21-22 de outubro de 1996b), Curitiba: CEFET-PR, p. 71-80.

OLIVEIRA, S. M. Derivação prefixal: um estudo sobre alguns prefixos do português brasileiro. Florianólolis: UFSC, 2004. Dissertação de Mestrado.

Aspectos da Derivação Prefixal e Sufixal no Português do Brasil. Florianópolis: UFSC, 2009. Tese de Doutorado. 
PERINI, M. A. Gramática descritiva do português. 4ª Ed. São Paulo: Ática, 2007.

ROCHA, L. C. Estruturas Morfológicas do Português. 2a Ed. São Paulo: Editora Martins Fontes, 2008.

ROCHA LIMA, C. H. Gramática normativa da língua portuguesa. 47aㅗ ed. Rio de Janeiro: José Olympio, 2008.

ROSCH, E. Natural categories. Cognitive Psychology, v. 4, p. 328-350, 1973.

.; MERVIS, C. B. Family resemblances: studies in the internal structure of categories. Cognitive Psychology, v. 7, p. 573-605, 1975.

et al. Principles of categorization. In: $\mathrm{ROSCH}$, E.; LLYOD, B. B. (Eds.). Cognition and categorization. Hillsdale, N.J.: Erlbaum,1978.

SANTOS, A. P. 2016. Morfologia em diacronia - os caminhos e desvios de um afio na história da língua: o percurso históricosemântico do prefixo des- em bases sufixadas e em formações parassintéticas. Tese (Doutorado em Filologia e Língua Portuguesa), Faculdade de Filosofia, Letras e Ciências Humanas, USP, São Paulo.

SAUSSURE, Ferdinand. Curso de Linguística Geral. 28aㅡ ed. São Paulo: Editora Cultrix, 2012 [1916].

SCHNEIDER, L. \& BIDARRA, J. O comportamento semântico do prefixo "des-": questões de polissemia e produtividade lexical. Línguas \& Letras, v. 10, n. 18, p. 71-84, 2009.

SILVA, M. C. F.; MIOTO, C. 2009. Considerações sobre a prefiação. ReVEL, v. 7, n. 12: 1-22.

SILVA, A. S. A linguística cognitiva - uma breve introdução a um novo paradigma em linguística. Revista Portuguesa de Humanidades, v. 1, n. 1-2, p. 59-101, 1997.

SMITH, E. E.; MEDIN, D. L. Categories and concepts. Cambridge, Massachusetts: Havard University Press, 1981.

TRASK, R. L. Dicionário de linguagem e linguística. São Paulo: Editora Contexto, 2006. 
7.

\section{Apêndice}

Nesta seção serão disponibilizadas as outras palavras em seus contextos de uso coletadas no corpus bem como a descrição do sentido do prefixo "des-" nestas construções. Além disso, informamos ainda que os vocábulos também serão apresentados em seções separadas estabelecidas a partir de seus sufixos formadores.

\section{1.}

Vocábulos formados a partir do sufixo "-ção"

1. O objetivo era forçá-los a desobstruir a rodovia PA-150, que tinham ocupado para protestar contra o atraso na desapropriação de terras para reforma agrária.

\section{Reversão de estado}

2. O ministro anunciou que no próximo fim de semana o presidente Fernando Henrique deverá se reunir com os governadores para discutir a descentralização do processo de reforma agrária.

\section{Reversão de estado}

3. O processo de desindexação vem se realizando desde a implementação da nova moeda, o real.

\section{Reversão de processo}

4. A desregulamentação dos setores de telecomunicações, petróleo e gás e elétrico pode gerar uma avalanche de investimentos privados no Brasil nestes setores.

\section{Reversão de estado}


5. A primeira fase do projeto de despoluição do rio Tietê vai terminar com, no mínimo, dois anos de atraso.

\section{Reversão de estado}

6. “A desintegração da federação nos anos 90 foi produto de um surto de nacionalismo, que vinha se fortalecendo dentro das repúblicas mesmo sob os rígidos controles impostos por Tito", afirmou ele.

\section{Reversão de estado}

7. Luiz Inácio Lula da Silva comunicou oficialmente à Igreja que a defesa da descriminalização do aborto e do reconhecimento dos direitos previdenciários de casais homossexuais não constará do seu programa de governo.

\section{Reversão de estado}

8. A perda de quantidades excessivas de água pode levar à desidratação, doença de grande incidência no nosso país, que atinge principalmente as crianças durante o verão.

\section{Reversão de estado}

9. Já há algum tempo diversos membros do governo discutem quais os caminhos que podem ser tomados para o programa de desestatização.

\section{Reversão de estado}

10. Assim, uma parte importante do esforço de Rorty envolve uma reconstrução, ou desconstrução, do pensamento filosófico ocidental em uma tentativa de mostrar as várias maneiras nas quais a Filosofia deu errado.

\section{Oposição}

11. O presidente também quer evitar a desagregação de sua base de apoio devido às divergências programáticas quanto ao ritmo e a intensidade da abertura da economia. 


\section{Reversão de estado}

12. Alguns proprietários de hospitais do Rio, estão preparando um movimento de desvinculação do Sindicato dos Estabelecimentos de Saúde.

\section{Reversão de estado}

13. A criação, fomento e incremento do emprego passa pela desburocratização e pela retirada da presença excessiva do Estado nos negócios privados.

\section{Reversão de estado}

14. O presidente continua sendo um fator potencial de desestabilização das medidas econômicas, mas, até agora, todas as ameaças de intervenção junto à equipe econômica ficaram na retórica.

\section{Negação}

15. Fica a pergunta: diante desta perspectiva, será que o feminismo está fora de moda ou a desqualificação sistemática que ele está sofrendo não será resistência dos velhos padrões que não querem morrer?

\section{Oposição}

16. Além da evidente desmobilização da esquerda, incapaz de enfrentar a maioria absoluta de Balladur (que reúne os dois partidos de centro-direita, o seu RPR e a UDF), o primeiro-ministro conta ainda com a confiança da classe média.

\section{Negação}

17. Com o movimento de descolonização da África e da Ásia, acentuado a partir do final da Segunda Guerra Mundial, surgiu nesses continentes grande número de países.

\section{Reversão de processo}


18. Como a realidade é outra, como os índios agora viajam de avião e barco a motor, comem enlatados e padecem de todas as doenças dos brancos, as fotos devem desmentir essa realidade, recortá-la e filtrá-la de toda a descaracterização.

\section{Reversão de estado}

19. Fico incomodado de ver nas universidades, em especial nas públicas, a desproporção entre os alunos egressos de escolas privadas (que poderiam até pagar uma faculdade) e os que vieram de escolas públicas.

\section{Negação}

20. Quem trabalha com essa questão no dia-a-dia sabe que é um problema sério», pondera Biscaia, que tratou recentemente da atriz Vera Fischer, internada para se submeter a um processo de desintoxicação.

\section{Reversão de estado}

21. A modernização passa pela profissionalização e despolitização do serviço público, por seu enxugamento, pela proibição de indicações políticas de qualquer natureza para a máquina pública, pelo respeito ao equilíbrio orçamentário.

\section{Reversão de processo}

22. Temos tecnologia, solo, clima e condições de nos tornarmos uma potência no agribusiness, sem que isto implique em políticas suicidas de desindustrialização forçada ou abandono das cidades.

\section{Oposição}

23. A desarticulação da bancada ruralista, proveniente apenas da falta de motivos para a luta nos últimos dois anos, foi tomada como enfraquecimento profundo.

\section{Negação}


24. A própria denominação de rede, utilizada pelas concessionárias (Rede Globo, Rede Bandeirantes, etc) prova que o princípio da desconcentração é desrespeitado.

\section{Negação}

25. São aspectos dramáticos da desorientação que cega as elites das classes dominantes, que vivem no Brasil, mas enxotam do pensamento as necessidades pungentes do povo.

\section{Negação}

26. Interdição - A desaprovação aos dois projetos da prefeitura será manifestada ainda esta semana por estudantes e moradores da Gávea.

\section{Negação}

27. O primeiro país a adotar essas medidas (antes mesmo de virarem "regras globais") foi o Chile, durante o regime Pinochet, com os resultados conhecidos sobre a desestruturação dos bancos e da indústria.

\section{Oposição ou reversão de estado}

28. A desumanização das massas de estudantes pobres opera como a condição necessária para a morte cívica do eleitor.

\section{Oposição ou reversão de estado}

29. Mas é bom lembrar que é notória a despreocupação de políticos tradicionais com o equilíbrio das contas públicas, sobretudo num ano eleitoral.

\section{Negação}

30. Outra proposta que caiu facilmente foi do deputado Eduardo Jorge: a desmilitarização do país. 


\section{Reversão de estado}

31. "O que nos surpreende é a força e a ferocidade dos explosivos usados e a total desconsideração (dos terroristas) por suas vidas e de qualquer outra pessoa", disse Condon.

\section{Negação}

32. A nova moral, que vigora em boa parte do Ocidente, envolve a dessacralização e a desmistificação da sexualidade.

\section{Reversão de estado}

33. A ideologia neoliberal, que apresenta o processo de desregulação financeira como inegavelmente virtuoso, combinada com a inércia, o medo e o parasitismo de nossas elites privadas e públicas, tem sido um dos maiores obstáculos psicológicos à nossa capacidade de reagir e tentar defender a nação como espaço de solidariedade.

\section{Reversão de estado}

34. O assessor especial da Fazenda, Edmar Bacha, defende a "desconstitucionalização" dos capítulos referentes a tributação e Previdência Social imediatamente, ou seja, durante o governo Itamar.

\section{Reversão de estado}

35. "Estou fazendo uma descoloração por dia", diz o cabeleireiro Tiago Alves dos Santos, dono de um salão sintomaticamente chamado Blondie (loiro em inglês) e, ele próprio, um recém-convertido à tribo dos cabeçasbrancas.

\section{Reversão de estado}

36. O engenheiro responsável pelo trabalho de desobstrução do túnel próximo a Muriqui, Ivan Carvalho, da empresa Rodoferrea, contratada pelo DNER, disse que o desmoronamento ocorreu por volta das $10 \mathrm{~h}$. 


\section{Reversão de processo}

37. O desemprego, a deseducação, a falta de saneamento, a desnutrição são a porta de entrada das doenças e epidemias.

\section{Negação (por falta)}

38. Por exemplo, os dois reafirmaram seu compromisso com a desnuclearização da península da Coréia e concordaram com a possibilidade de aplicar sanções econômicas contra a Coréia do Norte caso ela resolva construir armas nucleares.

\section{Reversão de estado}

39. Essa cunha fiscal, disse Schulamnn, reduz o rendimento das aplicações feitas pelos investidores e aumenta o custo dos tomadores de empréstimos, estimulando a desintermediação financeira, como indica o crescimento dos cheques pré-datados e outras operações que passam fora do sistema bancário.

\section{Negação}

40. Aqui, em curtíssimo espaço de tempo, por absoluta falta de política agrícola, o campo sofreu abrupta descapitalização.

\section{Negação (perda)}

41. O brasileiro Sérgio Rojas dedilha o seu violão japonês e, com a desinibição que lhe é característica, começa a cantar num altíssimo falsete.

\section{Negação}

42. A enchente também revelou incompetência e descoordenação.

\section{Negação}


43. Estou muito interessado em provar a desmaterialização dos sólidos, por exemplo, de uma forma óptica, já que sou um artista plástico.

\section{Negação}

44. O kit contém informações sobre a doença, sais reidratantes, uma colhermedida para a preparação do soro caseiro e hipoclorito de sódio para descontaminação da água.

\section{Reversão de estado}

45. O econômico, social, cultural e político são interdependentes e instrumentais para converter a luta de classes em fator de desalienação e desemburguesamento.

\section{Reversão de estado}

46. Assim, pôde o MDB investir contra a falta de justiça social, denunciando a má distribuição de renda, contra a falta de liberdades civis, apontando as violações dos direitos humanos, e contra a desnacionalização da economia, denunciando o controle dos capitais estrangeiros sobre a economia brasileira.

\section{Oposição ou reversão de estado}

47. Nos contos desse autor, que analisa com rara percuciência, Julia Marchetti sublinha o vazio, a despersonalização e a automatização da vida proletária isomorficamente narradas numa linguagem de calculada pobreza e aridez.

\section{Negação}

48. A maior parte das angiospermas apresenta, além do crescimento longitudinal, crescimento em espessura, que ocorre graças ao câmbio fascicular e à desdiferenciação de células adultas em células meristemáticas. 


\section{Negação}

49. "O risco da violência na TV está no aprendizado de como agir violentamente, na dessensibilização para as consequências prejudiciais da violência e num medo maior de ser vítima da violência", diz o estudo, calculando que $73 \%$ dos atos de violência na TV não são punidos, o que transmite às crianças a idéia de que a violência compensa, ou pior, de que é um divertimento.

\section{Negação}

50. Será duro para o presidente engolir mais este sapo - da mesma forma como deve ter sido difícil a encenação da desautorização de Tasso Jereissati - mas nessa altura há mais que ossos do ofício em jogo.

\section{Reversão de estado}

51. No segundo tempo, o segundo gol do São Paulo causou uma certa desarrumação no nosso time.

\section{Negação ou reversão de estado}

52. [os programas] Têm recurso automático para compactação e descompactação de arquivos de áudio, microfone externo e interface de som MIDI.

\section{Reversão de processo}

53. A desglamourização é uma tendência que começou no final dos anos 80 e se alastrou aos anos 90.

\section{Negação ou oposição}

54. Foi sobretudo devido ao sutil trabalho larápio dessa mão boba que Betinho resolveu pôr de lado a desmonopolização e a desregulamentação para pedir, ao som de sua viola, que pelo amor de Deus não esperemos sair de crise mediante a morte, no menor prazo possível, dos 32 milhões de tristes que não têm o que comer no dia de hoje. 


\section{Reversão de estado}

55. Nos casos mais radicais, estamos diante de uma desidentificação: ninguém quer se identificar com um soropositivo, com um refugiado na Albânia.

\section{Negação ou oposição}

56. Na Internet, por mais descentralização e desterritorialização que incentive, sempre vai existir gente chata, autoritarismos de todas as espécies.

\section{Reversão de estado}

57. Os imaginários coloniais, bem como os de hoje, praticavam a descontextualização e o reemprego, a desestruturação e a reestruturação das linguagens.

\section{Negação}

58. Se a primeira versão com Warren Beatty e Faye Duanaway já era uma idealização do fato real de dois pobres diabos filhos da grande crise americana, esta versão escrita e dirigida por Gary Hoffman e estrelada por Tracy Weedham e Dana Ashbrook tenta ser a desdramatização de uma fantasia romântica, só que em vez de buscar o que realmente aconteceu, paraliza-se como um pseudo documentário ingênuo onde se tenta chegar à «verdade» pelo esvaziamento de qualquer espetáculo.

\section{Oposição ou negação}

59. A Secretaria Municipal de Organização Social Fundiária de Manaus entregará em 10 de outubro 80 casas a famílias carentes, como parte do programa de desfavelização.

\section{Reversão de estado}

60. Passaram-se para a sala de visitas, e ela, com um grande acanhamento e um pouco de desafinação, executou vários trecho italianos. 


\section{Negação (por falta)}

61. A descontinuação desses modelos depende do comportamento do mercado.

\section{Negação}

62. Roberto Felício, presidente do sindicato dos professores, alega que, por causa dos salários baixos, há uma "desprofissionalização da categoria", o que ajudaria a explicar a gazeta docente.

\section{Oposição ou negação (por falta)}

63. Poderia parecer que uma atitude transgressiva ou desconstrutiva no universo dos simulacros digitais deveria passar necessariamente por um processo de "desprogramação", por um détournement da técnica, ou por qualquer distorção de suas funções simbólicas.

\section{Reversão de processo}

64. Atualmente, o vácuo espiritual que resulta de nossa perda da razão dialética está sendo preenchido por todas espécies de movimentos dúbios de misticismo e ocultismo, uma tendência perigosa que tem verdadeiramente encorajado o ideal da desincorporação do intelecto e do academicismo clássico que Blake certamente achou revoltante.

\section{Negação}

65. Consultas preliminares feitas pela mídia americana a congressistas e agentes do DEA, a agência de combate às drogas, indicam que todos preferem a opção radical da "descertificação", para chamar a atenção dos colombianos para o problema da droga e manter a credibilidade de leis e mecanismos legislativos dos EUA.

\section{Reversão de estado}

66. O enxugamento da máquina emperrada, a "desprivatização" do Estado loteado pela "corrupção legal" dos privilégios seculares abriria caminho para exigências populares mais radicais. 
Reversão de estado

\section{2.}

\section{Vocábulos formados a partir do sufixo "-mento"}

67. Haverá desabastecimento de produtos agrícolas após setembro, aposta o presidente da CNA (Confederação Nacional da Agricultura), Antônio Ernesto de Salvo.

\section{Negação}

68. Caso o estudo comprove que estão ocorrendo danos ao meio ambiente, a procuradora deverá pedir o desligamento das luzes nos três morro.

\section{Reversão de estado}

69. O desalinhamento das rodas faz com que o carro perca a estabilidade, além de provocar desgaste excessivo de pneus, da suspensão, consumo elevado de combustível.

\section{Negação}

70. Ficará evidente que não concordo com aqueles que veem a filosofia como a história de erros tolos e o progresso da filosofia como o desmascaramento de erros tolos.

\section{Reversão de estado}

71. O deslizamento das placas tectônicas gera alterações na aparência da superfície da Terra, causando dobramentos (deformação, sem quebra entre camadas) e falhas (rupturas e desnivelamento entre camadas).

\section{Reversão de estado}

72. Durante anos houve desinvestimento na África do Sul: as companhias, especialmente as norte-americanas, deixaram o país por causa das sanções impostas ao governo sul-africano. 


\section{Negação}

73. O amplo mercado interno e a persistência durante muito tempo de alíquotas do Imposto de Importação fixadas a níveis proibitivos tornaram o contrabando uma atividade altamente rentável e com poucos riscos, em face do desaparelhamento das instituições destinadas a combatê-lo.

\section{Negação (por falta)}

74. Quanto à desertificação de determinadas áreas, o principal fator que tem contribuído para tal é o contínuo processo de desflorestamento que determinadas áreas florestais têm sofrido.

\section{Reversão de processo ou oposição}

75. Na última quinta, o prédio da Cásper Líbero havia sido parcialmente interditado pelo Contru por não apresentar sistema de alarme, 'escadas de emergência e portas corta-fogo com destravamento automático.

\section{Reversão de estado}

76. Os pseudônimos que usava para seus trabalhos estéticos, embora não enganassem ninguém (pelo menos em Copenhage), uma marca que queria ver bem assinalada, de seu descomprometimento com relação às ideias expressas nesses trabalhos.

\section{Negação}

77. As irregularidades mais comuns encontradas nos fundos de pensão são o desenquadramento das aplicações financeiras, insuficiência de recursos de reserva, insuficiência patrimonial e problema da administração da carteira de imóveis.

\section{Negação}

78. Para o ex-governador, o presidente fez "um desmerecimento ao Rio de Janeiro" ao ficar tão pouco tempo na solenidade. 


\section{Oposição}

79. Subir em guias, passar em buracos e raspar os pneus na calçada são as principais causas do desbalanceamento dos aros.

\section{Reversão de estado ou negação}

80. Em sua luta por justiça, ele também "tá combatendo mais de dois séculos de despovoamento rural e de crescente eficiência agrícola".

\section{Reversão de processo}

\section{3.}

\section{Substantivos deverbais}

81. Ontem e anteontem, a Feema recebeu dezenas de reclamações sobre o desconforto causado pela poluição.

\section{Reversão de estado}

82. Porta-voz dos pais do Real, o secretário de Política Econômica do Ministério da Fazenda, José Roberto Mendonça de Barros, reconheceu que o ajuste do setor público tem sido lento, mas rebateu o desânimo dos economistas com números mostrando que os juros estão baixando, a situação fiscal melhorou, a inflação caiu e os investimentos externos aumentaram.

\section{Reversão de estado}

83. Apesar desse desencontro de temas, a ideia da greve geral está viva.

\section{Negação}

84. A desilusão dos investidores, porém, não tem origem apenas nas projeções dos profissionais do mercado financeiro.

\section{Reversão de estado}


85. Ainda na mesma fala de Eufrosina, veja-se uma estrutura arcaica («sua mucama dela), aliás, neste livro, muito repetida nas personagens negras, demonstrando, portanto, a consciência que o autor tinha da ligação entre as estruturas em desuso na linguagem da cidade e a fala das comunidades rurais, realidade linguística que seria amplamente explorada pela obra Inocência do Visconde de Taunay, publicada um ano depois de $\mathrm{O}$ Tronco do Ipê.

\section{Negação}

86. A situação dos servidores públicos da administração direta é de tamanha penúria salarial, de extremo desamparo, que a luta sindical consegue, quando muito, conquistas para assegurar muito pouco além da própria sobrevivência.

\section{Negação}

87. Fechar os olhos para o abismo que 'tá se criando entre os níveis da pesquisa e do ensino é querer premiar o descompromisso com a transmissão do conhecimento e com formação de pessoal qualificado.

\section{Negação}

88. O juiz de Curionópolis, Laércio de Almeida Laredo, determinou ontem mesmo o desbloqueio da estrada, através de uma ação declaratória negativa de direitos dirigida às entidades representativas dos garimpeiro.

\section{Reversão de estado}

